\title{
Growth, Feeding and Fecundity of Fish in Gleniffer Lake (Dickson Dam Reservoir)
}

\author{
CANADRENA \\ C 2 \\ MAR 261991
}


Digitized by the Internet Archive in 2016 
GROWTH, FEEDING AND FECUNDITY OF FISH IN

GLENIFFER LAKE (DICKSON DAM RESERVOIR)

\author{
by \\ James W. Moore \\ Aquatic Biology Branch \\ Alberta Environmental Centre \\ Vegreville, Alberta
}

August 29, 1990 
This report may be cited as:

Moore, J.W. 1990. Growth, Feeding and Fecundity of Fish in Gleniffer Lake (Dickson Dam Reservoir). Alberta Environmental Centre, Vegreviile, AB. AECV90-R4. 40 pp. 
LIST OF TABLES $\ldots \ldots \ldots \ldots \ldots \ldots \ldots \ldots \ldots \ldots \ldots \ldots \ldots \ldots \ldots \ldots$

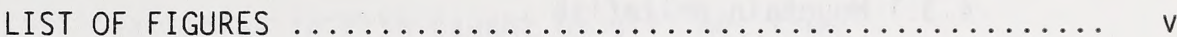

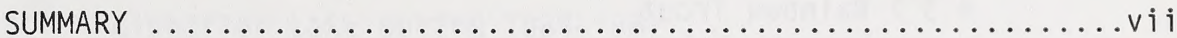

PROJECT TEAM ..........................

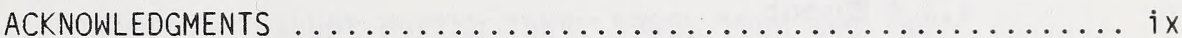

1. INTRODUCTION $\ldots \ldots \ldots \ldots \ldots \ldots \ldots \ldots \ldots \ldots \ldots \ldots \ldots \ldots \ldots \ldots$

1.1 Background $\ldots \ldots \ldots \ldots \ldots \ldots \ldots \ldots \ldots \ldots \ldots \ldots \ldots \ldots \ldots \ldots \ldots$

1.2 Purpose of Study $\ldots \ldots \ldots \ldots \ldots \ldots \ldots \ldots \ldots \ldots \ldots \ldots \ldots$

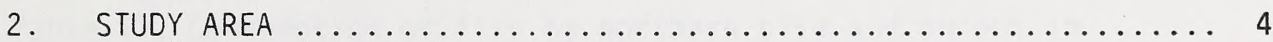

2.1 Red Deer River ......................... 4

2.2 History of Dam and Reservoir Facility ............. 4

2.3 History of Fish Plantings $\ldots \ldots \ldots \ldots \ldots \ldots \ldots \ldots \ldots \ldots$

3. MATERIALS AND METHODS ....................... 5

3.1 Fish Collections ........................ 5

3.1 .1 Beach Seine ........................... 5

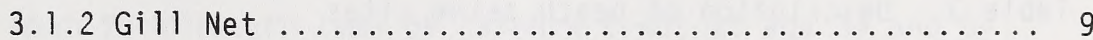

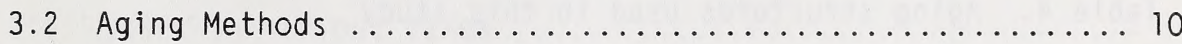

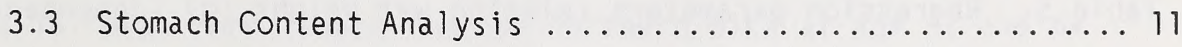

3.4 Fecundity Analysis .......................... 11

3.5 Statistical Methods ........................... 12

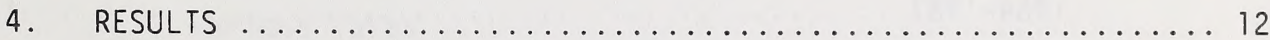

4.1 Length/Weight Relation .......................... 12

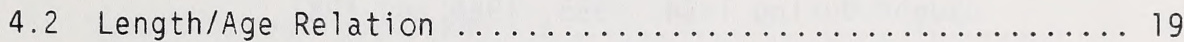


4.3 Stomach Contents ............................ 27

4.3.1 Mountain Whitefish ....................... 27

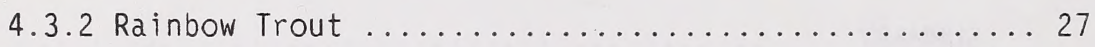

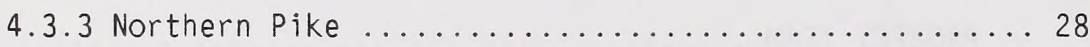

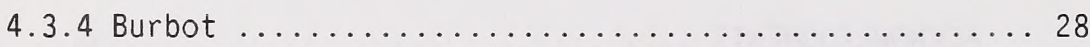

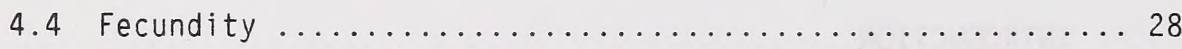

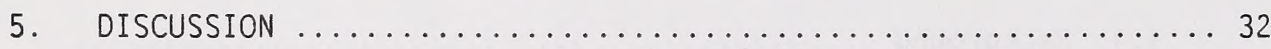

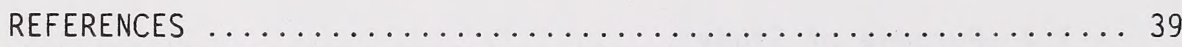

LIST OF TABLES

Table 1. Summary of information on Dickson Dam, Gleniffer Lake and surrounding area $\ldots \ldots \ldots \ldots \ldots \ldots \ldots \ldots \ldots \ldots \ldots \ldots \ldots \ldots \ldots \ldots \ldots$

Table 2. Summary of fish plantings carried out at Gleniffer Lake . 7

Table 3. Description of beach seine sites $\ldots \ldots \ldots \ldots \ldots \ldots \ldots$

Table 4. Aging structures used in this study $\ldots \ldots \ldots \ldots \ldots . \ldots . \ldots$

Table 5. Regression parameters relating wet weight (g) (dependent variable) to fork length (mm) (independent variable) in fish caught by gill net from Gleniffer Lake during 1984-1987

Table 6. t-test of regression slops relating age to weight for fish caught during 1984, 1985, 1986 and 1987 
Table 7. Regression parameters relating fork length (mm)

(independent variable) to age (years) (dependent

variable) in fish caught by gill net from

Gleniffer Lake during 1984-1987

Table 8. t-test of regression slopes relating age to fork length for fish caught during 1984, 1985, 1986 and $1987 \ldots \ldots .21$

Table 9. Fork length (mm) of fish of standard age (years) collected by gill net from Gleniffer Lake during 1984-1987

Table 10. Summary of stomach content analyses

Table 11. Consumption of fish by northern pike and burbot in

Gleniffer Lake 1984-87

Table 12. Regression parameters relating length ( $\mathrm{mm}$ ) to calculated total number of eggs in fish caught by gill net from Gleniffer Lake during 1984-1987

Table 13. Mean fork length (mm) of mountain whitefish at age $3+$ and $6+$ years in various lakes and rivers

Table 14. Mean fork length $(\mathrm{mm})$ of rainbow trout at age $3+$ and $6+$ years in various lakes

Table 15. Mean fork length (mm) of northern pike at age $3+$ and $6+$ years in various Alberta lakes .................... 36

Table 16. Mean fork length (mm) of burbot at age $3+$ and $6+$ years in various lakes

Table 17. Mean fork length (mm) of white sucker at age $3+$ and $6+$ years in various lakes 
Table 18. Mean fork length $(\mathrm{mm})$ of longnose sucker at age $3+$ and $6+$

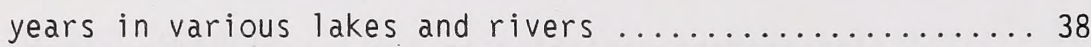

\section{LIST OF FIGURES}

Figure 1. Location of Gleniffer Lake .................. 2

Figure 2. Beach seine sampling sites ................. 8

Figure 3. Gill net sampling sites $\ldots \ldots \ldots \ldots \ldots \ldots \ldots \ldots \ldots$

Figure 4. Linear regression analys is ( $\pm 95 \%$ confidence limits) relating weight to length of mountain whitefish and rainbow trout collected by gill net from Gleniffer Lake

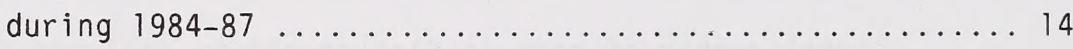

Figure 5. Linear regression analys is ( $\pm 95 \%$ confidence limits) relating weight to length of northern pike collected by gill net from Gleniffer Lake during 1984-87 ........ 15

Figure 6 . Linear regression analysis ( $\pm 95 \%$ confidence limits) relating weight to length of burbot collected by gill ret from Gleniffer Lake during $1984-87 \ldots \ldots \ldots \ldots$

Figure 7 . Linear regression analys is ( $\pm 95 \%$ confidence limits) relating weight to length of longnose sucker collected by gill net from Gleniffer Lake during 1984-87 
Figure 8. Linear regression analysis ( $\pm 95 \%$ confidence limits) relating weight to length of white sucker collected by gill net from Gleniffer Lake during $1984-87 \ldots \ldots \ldots \ldots 18$

Figure 9. Linear regression analysis ( $\pm 95 \%$ confidence 1 imits) relating length to age of mountain whitefish and rainbow trout collected by gill net from Gleniffer Lake during

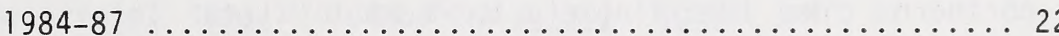

Figure 10 . Linear regression analys is ( $\pm 95 \%$ confidence 1 imits) relating length to age of northern pike collected by gill net from Gleniffer Lake during $1984-87 \ldots \ldots \ldots \ldots . \ldots 23$

Figure 11 . Linear regression analysis ( $\pm 95 \%$ confidence limits) relating length to age of burbot collected by gill net from Gleniffer Lake during $1984-87 \ldots \ldots \ldots \ldots \ldots 24$

Figure 12. Linear regression analysis ( $\pm 95 \%$ confidence limits) relating length to age of white sucker collected by gill net from Gleniffer Lake during $1984-87 \ldots \ldots \ldots \ldots 25$

Figure 13. Linear regression analysis ( $\pm 95 \%$ confidence limits) relating length to age of longnose sucker collected by gill net from Gleniffer Lake during 1984-87 ........ 26

Figure 14. Linear regression analysis ( $\pm 95 \%$ confidence limits) relating length to calculated total number of eggs of burbot, northern pike, rainbow trout, longnose sucker and white sucker collected by gill net from Gleniffer Lake during 1984-87 
Fish were collected by gill net and beach seine from a newly formed reservoir (Gleniffer Lake, Alberta) during a four-year period (1984-1987). The reservoir is located west of the City of Red Deer on the Red Deer River. Collections were made in the reservoir at standard sites and times throughout the study. Length, weight and age were determined for mountain whitefish (Prosopium williamsoni), northern pike (Esox lucius), burbot (Lota lota), white sucker (Catostomus commersoni), and longnose sucker (Catostomus catostomus). In addition, stomach content analysis was completed on mountain whitefish, rainbow trout, northern pike and burbot; fecundity was determined for rainbow trout (Oncorhynchus mykiss), northern pike, burbot, white sucker and longnose sucker. From these collections it was observed that:

1) mountain whitefish were initially trapped by the impoundment of the Red Deer River, but either died out or emigrated from the reservoir by 1985;

ii) growth of mountain whitefish and rainbow trout from the reservoir was greater than that observed for populations in many other Alberta lakes;

i i i) based on back-calculated growth rates, young ( $<3$ years old) northern pike apparently grew better in the Red Deer River than Gleniffer Lake whereas older pike (6+ years old) grew better in the reservoir than the river; this may have 
reflected a temporary reduction in food for young pike in the first years after impoundment;

iv) although growth of burbot was largely unaffected by impoundment, reduced growth of young burbot was noted during 1985

v) white sucker and longnose sucker grew significantly faster in the reservoir than the Red Deer River;

vi) although rainbow trout were planted in large numbers in the reservoir, they did not form a significant part of the diet of predacious species such as northern pike and burbot;

vii) the diet of mountain whitefish and rainbow trout was typical of that reported elsewhere in Canada and the USA;

viii) fecundity of rainbow trout, northern pike, burbot, white sucker, and longnose sucker was typical of that reported for other northern temperate zone lakes. 


\section{PROJECT TEAM}

$\begin{array}{ll}\text { Brenda Dew } & \text { James Moore } \\ \text { Karen Blumhagen } & \text { Ed Paleczny } \\ \text { Bernie Goski } & \text { David Park } \\ \text { John Craig } & \text { Dan Patton } \\ \text { Sandra Gellings } & \text { Jane Schneider } \\ \text { Lee George } & \text { James Somers } \\ \text { Darrel Katan } & \text { Kevin Smiley }\end{array}$

ACKNOWLEDGMENTS

We are indebted to staff from Fish and Wildlife Division (particularly D. Lowe, Head, Fisheries Management, Red Deer Region, and T. Mill, Director, Fisheries Management) for their assistance during this study. In addition, staff at the dam facility (T.J. Maduke, Reservoir Manager and his staff) provided essential logistic support for this study.

We are grateful to $M$. Barrett and $Z$. Florence for their assistance in reviewing and calculating much of the statistical data in this report.

We also wish to recognize M. Herbut for his assistance with the graphic presentation of data required for this report. 


\section{INTRODUCTION}

\subsection{Background}

Gleniffer Lake, located on the Red Deer River west of the City of Red Deer, was formed with the completion of the Dickson Dam in 1983 (Figure 1). The reservoir has an area of 1734 ha at full storage and measures approximately $11 \mathrm{~km}$ in length and $2 \mathrm{~km}$ in width. The facility provides two primary benefits: i) an assured water supply for downstream communities, and i i) improved water quality downstream.

During the spring and summer, runoff water is captured in the reservoir. Enough water is released during the winter to ensure a minimum flow of at least $16 \mathrm{~m}^{3} \mathrm{~s}^{-1}$. This rate of flow meets the present needs of downstream industries and communities including the Cities of Red Deer and Drumheller, and allows for future growth.

\subsection{Purpose of Study}

Because of its size and accessibility, the reservoir has the potential to become a significant sport fishing facility. The purpose of this report is to describe the growth, feeding and fecundity of major fish species in the reservoir. Such information is useful in managing the fisheries and, in particular, determining the nature and extent of fish plantings, and the relative success of different fish species.

A previous report (Alberta Environmental Centre, 1989a) concerning fish in the reservoir indicated that: 


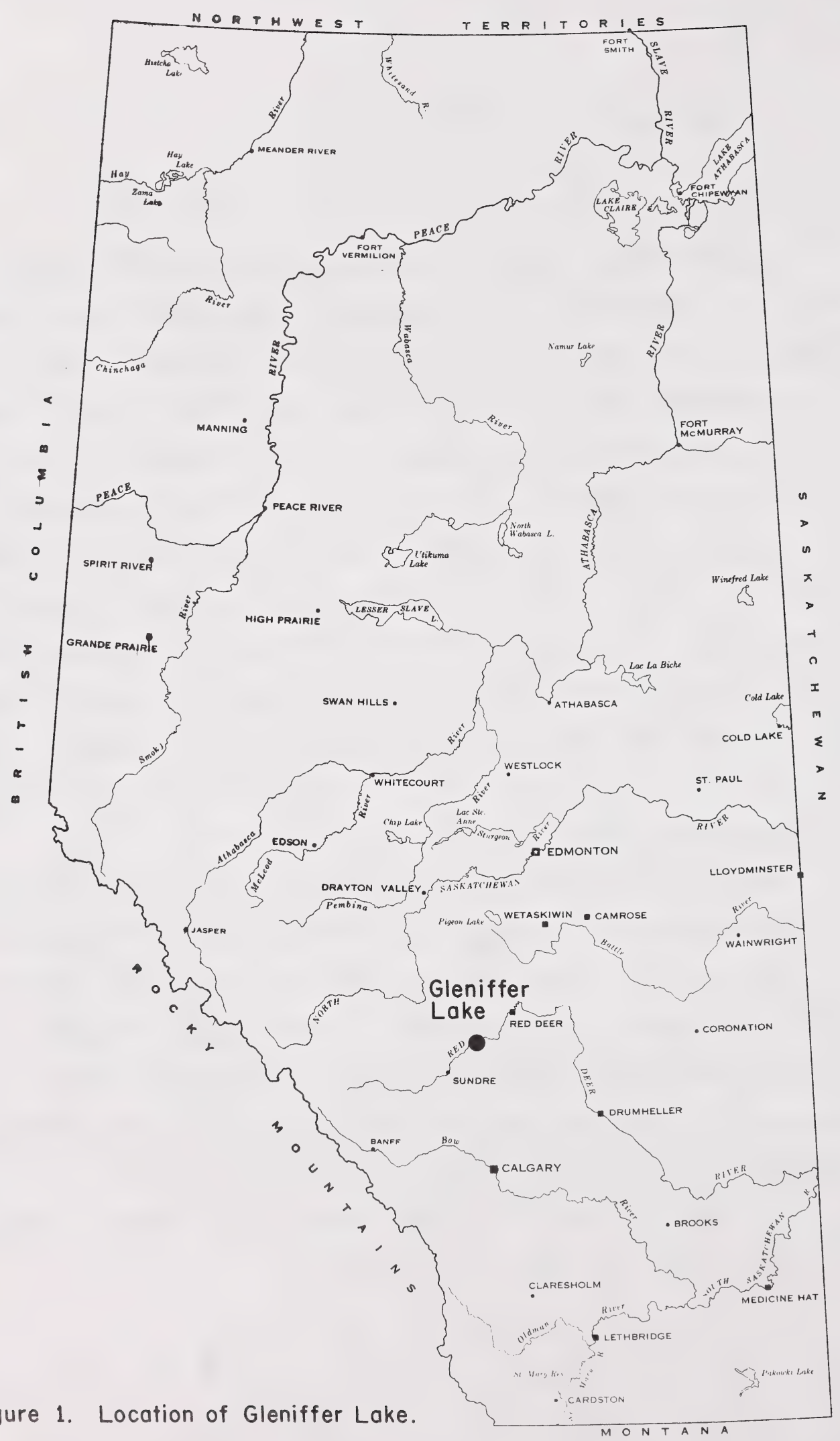

Figure 1. Location of Gleniffer Lake. 
i) the most frequently captured species in the reservoir were white sucker (Catostomus commersoni), longnose sucker (Catostomus catostomus), northern pike (Esox lucius), and burbot (Lota lota). Although rainbow trout (Oncorhynchus mykiss) had been planted in large numbers in the reservoir, they made up only a small part of the catch;

ii) the catch per unit effort (CUE) using gill nets was low, ranging from $1-4.7$ fish (all species) per $1000 \mathrm{~m}$ net per $\mathrm{h}$;

iii) planted rainbow trout and brown trout (Salmo trutta) apparently failed to spawn in the reservoir;

iv) the populations of northern pike, white sucker, longnose sucker and burbot apparently expanded immediately after impoundment, and later decreased in numbers;

v) the most frequently captured fish by anglers were rainbow trout, brown trout and northern pike;

vi) the CUE for angling was extremely low; depending on year, 11-45 $\mathrm{h}$ were required to angle one fish.

Another report (Alberta Environmental Centre, 1989b) concerning mercury in fish from the reservoir indicated that:

i) residues were low, generally $<500 \mu \mathrm{g} \mathrm{kg}^{-1}(0.5 \mathrm{ppm})$ in all species;

ii) there was no increase in tissue residues as the reservoir aged;

iii) no limits needed to be placed on consumption of fish from Gleniffer Lake. 


\section{STUDY AREA}

\subsection{Red Deer River}

The Red Deer River originates in Banff National Park at an elevation of approximately $1830 \mathrm{~m}$ above sea level. The river flows $185 \mathrm{~km}$ through the Rocky Mountains to Gleniffer Lake which is at an elevation of $948 \mathrm{~m}$ above sea level at Full Storage Level (FSL). The drainage area to this point is $5520 \mathrm{~km}^{2}$. The river continues a further $571 \mathrm{~km}$ eastward across parkland and prairies where it joins the South Saskatchewan River near Alberta's border with Saskatchewan.

\subsection{History of Dam and Reservoir Facility}

Technical studies began in 1971 and, after five years of investigations and a series of public hearings, a decision was made to build the dam. Clearing of the site and construction of access roads began in February 1980. By the spring of 1983, the dam was completed and the reservoir began filling.

The service spillway can handle any major flood of a magnitude occurring once in 10,000 years. In the unlikely event of a larger flood, an emergency spillway could be used to divert excess flow. A flood forecasting system using remote rainfall gauges and satellite communications gives early warning to operators about oncoming floods. The diversion tunnels are equipped for installation of hydroelectric power facilities, if needed. A summary of information on the dam and reservoir is listed in Table 1. 


\subsection{History of Fish Plantings}

Rainbow trout and cutthroat trout (Salmo clarki) were first planted in Gleniffer Lake in 1983 (Table 2). The introductions of rainbow trout continued through 1987, but no further cutthroat trout were planted beyond 1983. Brown trout were introduced to the reservoir only during 1984. Total plantings for all species exceeded one million fish.

\section{MATERIALS AND METHODS}

\subsection{Fish Collections}

Fish used in this study were collected with gill nets and beach seine during 1984, 1985, 1986 and 1987.

\subsubsection{Beach Seine}

The seine net was $18 \mathrm{~m}$ in length, $1.8 \mathrm{~m}$ in depth with a center bag of $1.8 \mathrm{~m} \times 1.8 \mathrm{~m}$. The mesh was $6.4 \mathrm{~mm}$ delta white nylon except for the bag which had a mesh of $3.2 \mathrm{~mm}$.

Four sites in each of three basins (west, central and east) were selected for a total of 12 sites (Figure 2, Table 3 ). These sites were sampled once a month from May through September.

After capture, fish were given a lethal dose of the anaesthetic MS222, weighed and measured, and then preserved in $10 \%$ formalin for later identification and enumeration. Stomach contents and gonads were preserved in a $10 \%$ formalin solution. 
Table 1. Summary of information on Dickson Dam, Gleniffer Lake and surrounding area.

Crest Length

Height

Volume of Fill

Crest Elevation

Length

Diameter

Design Discharge

Weir Elevation

Weir Length

Structure Length

Vertical Gates (5)

Design Discharge

Channel Width

Design Discharge

Flooded Area (Full Storage LeveL)

Usable Storage

Reservoir Length

Reservoir Width

Full Storage Level

Annual Flush Rate

Proportion of Incoming Sediment Retained

Annual Amount of Sediment Retained

Life Expectancy

EMERGENCY SPILLWAY

RESERVOIR

Length (North Side)

Length (South Side)

DYKES

DRAINAGE BASIN

Area

Mean Run-off

SPILLWAY

\author{
$650 \mathrm{~m}$ \\ $40 \mathrm{~m}$ \\ $3,600,000 \mathrm{~m}^{3}$ \\ $952 \mathrm{~m}$
}

$$
\begin{aligned}
& 940.5 \mathrm{~m} \\
& 60 \mathrm{~m} \\
& 235 \mathrm{~m} \\
& 8.6 \times 9.6 \mathrm{~m} \\
& 2,600 \mathrm{~m}^{3} \mathrm{ss}^{-i}
\end{aligned}
$$

$130 \mathrm{~m}$

$2,800 \mathrm{~m}^{3} \mathrm{~s}^{-1}$

$$
\begin{array}{rl}
1,734 & \mathrm{ha} \\
203 & 10^{6} \mathrm{~m}^{3} \\
11 \mathrm{~km} \\
2 \mathrm{~km} \\
948 \mathrm{~m} \mathrm{elevation} \\
5.5 \times \\
88 \% \\
290,000 \mathrm{~m}^{3} \\
500 \text { yrs }
\end{array}
$$

$3.0 \mathrm{~km}$

$3.7 \mathrm{~km}$

$5,520 \mathrm{~km}^{2}$

$32 \mathrm{~m}^{3} \mathrm{yr}^{-1}$ 
Table 2. Summary of fish plantings carried out at Gleniffer Lake.

\begin{tabular}{|c|c|c|c|c|}
\hline Year & Species & Month(s) Planted & Number Planted & Length $(\mathrm{cm})$ \\
\hline $\begin{array}{l}1983 \\
1983\end{array}$ & $\begin{array}{l}\text { Rainbow Trout } \\
\text { Cutthroat Trout }\end{array}$ & $\begin{array}{l}\text { Sept. } \\
\text { Sept. }\end{array}$ & $\begin{array}{r}61,557 \\
135,635\end{array}$ & $\begin{array}{ll} & 4.8-\quad 20 \\
\sim & 5.5\end{array}$ \\
\hline $\begin{array}{l}1984 \\
1984\end{array}$ & $\begin{array}{l}\text { Rainbow Trout } \\
\text { Brown Trout }\end{array}$ & $\begin{array}{l}\text { June, Aug., Sept. } \\
\text { Aug., Sept. }\end{array}$ & $\begin{array}{r}152,600 \\
67,100\end{array}$ & $\begin{array}{l}6.4->20 \\
5.2->20\end{array}$ \\
\hline 1985 & Rainbow Trout & May, June, Aug. & 498,500 & $5.6-12$ \\
\hline $\begin{array}{l}1986 \\
1986\end{array}$ & $\begin{array}{l}\text { Rainbow Trout } \\
\text { Rainbow Trout }\end{array}$ & $\begin{array}{l}\text { Aug. } \\
\text { Sept., Oct. }\end{array}$ & $\begin{array}{r}180,00 \\
375\end{array}$ & $\begin{array}{l}>15 \\
>20\end{array}$ \\
\hline 1987 & Rainbow Trout & Aug. & 242 & $>20$ \\
\hline $\begin{array}{l}\text { TOTALS } \\
83-87\end{array}$ & $\begin{array}{l}\text { Rainbow Trout } \\
\text { Cutthroat Trout } \\
\text { Brown Trout }\end{array}$ & & $\begin{array}{r}893,274 \\
135,635 \\
67,100\end{array}$ & $\begin{array}{l}4.8->20 \\
5.5 \\
5.2->20\end{array}$ \\
\hline $\begin{array}{l}\text { GRAND } \\
\text { TOTAL }\end{array}$ & Trout (all species) & & $1,096,009$ & $4.8->20$ \\
\hline
\end{tabular}

SOURCE: Fish Planting Lists (1983-1987) issued by Alberta Forestry, Lands and Wildlife.

Table 3. Description of beach seine sites.

\begin{tabular}{lll}
$\begin{array}{c}\text { Location } \\
\text { see Fig. 2) }\end{array}$ & $\begin{array}{c}\text { Maximum Depth } \\
(\mathrm{m})\end{array}$ & $\begin{array}{l}\text { Description of } \\
\text { Bottom Texture }\end{array}$ \\
\hline East A & 2 & Cobble, sand \\
East B & 2 & Soft sand/clay \\
East C & 2 & Gravel, soft sand/clay \\
East D & 7.5 & Cobble \\
Central A & 2.5 & Sand/gravel \\
Central B & 3 & Soft sand/clay \\
Central C & 2 & Cobble, some sand \\
Central D & 4.5 & Sand \\
West A & 4 & Sand \\
West B & 2.5 & Cobble, sand \\
West C & 3 & Sand \\
West D & 4 & \\
\hline
\end{tabular}



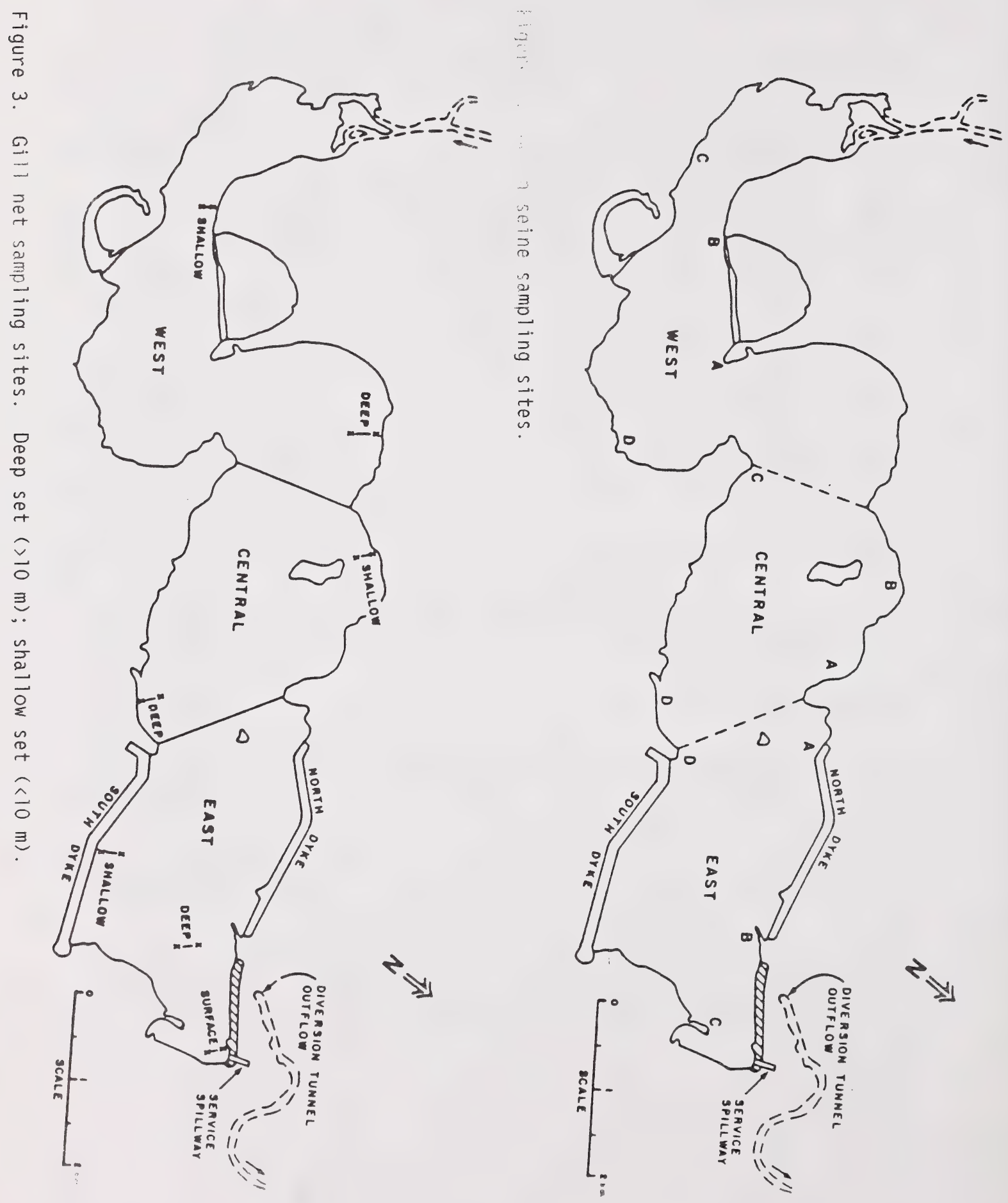


\subsubsection{Gill Net}

Multi-panel gill nets, measuring $50 \mathrm{~m}$ in length, were used in all collections. The nets, $1.8 \mathrm{~m}$ deep, were made of green or colourless monofilament nylon. Two nets were usually tied together, yielding a total length of $100 \mathrm{~m}$. Mesh sizes were $1.9,2.5,3.8,5.1,5.4,7.6$, $8.9,10.2,11.4$ and $12.7 \mathrm{~cm}$.

There were two sampling sites in each of the three basins (Figure 3$)$. One site was situated in shallow $(<10 \mathrm{~m})$ water and the other in deep $(>10 \mathrm{~m})$ water. Selection of an actual site was based on its suitability for gill netting, specifically minimum slope and minimum debris content.

Each net was set in the morning and left for $24 \mathrm{~h}$. The fish were taken to a field laboratory where the species, fork length, and wet weight of each fish were determined. Condition factor (Weight ${ }^{3} /$ Fork Length) was calculated. Stomach contents and ovaries were preserved in a $10 \%$ formalin solution. Aging structures were also taken (Table 4).

Table 4. Aging structures used in this study.

\begin{tabular}{lll} 
Species & Structure & Year \\
\hline Mountain Whitefish & Fin ray & 1984 \\
Rainbow Trout & Fin ray & 1986 \\
Burbot & Otolith & $1984,1985,1986$ \\
Northern Pike & Cleithrum & $1985,1986,1987$ \\
Operculum & 1984 \\
White Sucker & Fin ray & $1984,1986,1987$ \\
Scales & 1985
\end{tabular}




\subsection{Aging Methods}

All aging structures were placed in labelled envelopes. In the laboratory, the envelopes and structures were frozen at $-20^{\circ} \mathrm{C}$ until preparation. The preparation procedures used prior to aging were:

\section{Scales}

- Five scales were selected at random.

- The scales were cleaned with water and/or mildly basic solution and placed between two glass slides.

- The sides were taped, labelled and stored in a slide tray.

\section{Fin Rays}

- Two fin rays were air dried for 2-5 days.

- The proximal end of each ray was coated with epoxy and allowed to set for $24 \mathrm{~h}$.

- The ray was cut into 1-mm sections using a jeweller's saw.

- The sections were mounted with Diatex mounting fluid on a glass slide.

- The slides were labelled and stored in a slide tray.

\section{Cleithra and Opercula}

- One of each structure was first cleaned with warm water and soft brushes, then air dried and allowed to clear.

- Both structures were returned to the labelled scale envelope before evaluation. 


\section{Otoliths}

- Two otoliths were removed from each fish.

- Larger otoliths were sectioned and allowed to air dry. Small otoliths were air dried without sectioning.

- All structures were returned to the labelled envelope before evaluation.

Ages were determined for each specimen through the enumeration of annuli.

\section{3 Stomach Content Analysis}

The field-preserved stomach samples of rainbow trout, northern pike, mountain whitefish and burbot were sorted in the laboratory and identified according to five taxonomic classifications. Ingested fish were identified to species whenever possible. After identification, the samples were dried at $55^{\circ} \mathrm{C}$ to constant weight. Stomachs of other species were not examined due to time and financial restraints.

\section{4 Fecundity Analysis}

The ovary was sampled in six areas $(2 \times$ posterior, $2 \times$ middle, $2 \times$ anterior). A total of 1000 eggs (250 for rainbow trout) was counted from each of the six samples. The enumerated eggs were then dried to constant weight. The remainder of the ovary was also dried, thereby permitting an estimate to be made of total egg numbers.

Because mountain whitefish were caught only in 1984, at a time prior to sexual maturation, no determination of fecundity could be made of that species. 


\subsection{Statistical Analysis}

The following relationships were expressed as linear regressions: fork length-weight, fork length-age, fork length-number of eggs. Linear regression was used because it provided the best fit for the majority of data. The regression slopes relating fork length to age and fork length to weight were analyzed using the t-test.

\section{RESULTS}

\subsection{Length/Weight Relation}

The species collected in sufficient numbers to warrant analysis were northern pike, white sucker, longnose sucker, mountain whitefish, burbot, and rainbow trout. Mountain whitefish were collected only during 1984 whereas rainbow trout were collected in sufficient numbers to warrant analysis during 1986 and 1987. Only 3 brown trout, 1 brook trout (Salvelinus fontinalis) and 1 dolly varden (Salvelinus malma) and no cutthroat trout were caught during the entire study.

The linear regressions relating wet weight to fork length of the above-noted species are listed in Table 5 and graphed in Figures 4-8. The slopes of these regressions were analyzed using t-test (Table 6). In the case of rainbow trout and northern pike, there were no significant differences among slopes during the study. This means that the length-weight relationship remained constant for both species in all years. Burbot, on the other hand, carried more weight in fish of standard length caught in 1986 and 1987 compared to 1985. This can possibly be related to improved feeding conditions as the reservoir 
Table 5. Regression parameters relating wet weight (g) (dependent variable) to fork length ( $\mathrm{mm}$ ) (independent variable) in fish caught by gill net from Gleniffer Lake during 1984-1987.

\begin{tabular}{|c|c|c|c|c|c|c|}
\hline Year & Slope & Y-intercept & $r^{2}$ & Mean & $\begin{array}{l}\text { Condition } \\
\text { Factor* }\end{array}$ & $\mathrm{N}$ \\
\hline \multicolumn{7}{|c|}{ MOUNTAIN WHITEFISH } \\
\hline 1984 & 1.991 & -318 & 0.89 & & 1.06 & 24 \\
\hline \multicolumn{7}{|c|}{ RAINBOW TROUT } \\
\hline $\begin{array}{l}1986 \\
1987\end{array}$ & $\begin{array}{r}13.38 \\
8.15\end{array}$ & $\begin{array}{l}-4893 \\
-2236\end{array}$ & $\begin{array}{l}0.96 \\
0.60\end{array}$ & & $\begin{array}{l}1.33 \\
1.43\end{array}$ & $\begin{array}{r}11 \\
6\end{array}$ \\
\hline \multicolumn{7}{|c|}{ NORTHERN PIKE } \\
\hline $\begin{array}{l}1984 \\
1985 \\
1986 \\
1987\end{array}$ & $\begin{array}{l}6.063 \\
8.201 \\
7.685 \\
6.946\end{array}$ & $\begin{array}{l}-1905 \\
-3018 \\
-2740 \\
-2148\end{array}$ & $\begin{array}{l}0.59 \\
0.90 \\
0.86 \\
0.85\end{array}$ & & $\begin{array}{l}0.89 \\
0.82 \\
0.77 \\
0.76\end{array}$ & $\begin{array}{l}23 \\
35 \\
20 \\
25\end{array}$ \\
\hline \multicolumn{7}{|c|}{ BURBOT } \\
\hline $\begin{array}{l}1984 \\
1985 \\
1986 \\
1987\end{array}$ & $\begin{array}{l}3.366 \\
4.595 \\
5.472 \\
6.968\end{array}$ & $\begin{array}{r}-861 \\
-1441 \\
-1796 \\
-2870\end{array}$ & $\begin{array}{l}0.89 \\
0.91 \\
0.90 \\
0.97\end{array}$ & & $\begin{array}{l}0.61 \\
0.57 \\
0.59 \\
0.50\end{array}$ & $\begin{array}{r}11 \\
10 \\
13 \\
6\end{array}$ \\
\hline \multicolumn{7}{|c|}{ WHITE SUCKER } \\
\hline $\begin{array}{l}1984 \\
1985 \\
1986 \\
1987\end{array}$ & $\begin{array}{l}5.069 \\
3.831 \\
4.939 \\
4.959\end{array}$ & $\begin{array}{r}-1110 \\
-694 \\
-1087 \\
-1078\end{array}$ & $\begin{array}{l}0.91 \\
0.94 \\
0.93 \\
0.94\end{array}$ & & $\begin{array}{l}1.47 \\
1.37 \\
1.39 \\
1.44\end{array}$ & $\begin{array}{l}31 \\
54 \\
50 \\
67\end{array}$ \\
\hline \multicolumn{7}{|c|}{ LONGNOSE SUCKER } \\
\hline $\begin{array}{l}1984 \\
1985 \\
1986 \\
1987\end{array}$ & $\begin{array}{l}3.876 \\
5.376 \\
6.161 \\
5.048\end{array}$ & $\begin{array}{r}-762 \\
-1304 \\
-1621 \\
-1168\end{array}$ & $\begin{array}{l}0.91 \\
0.88 \\
0.84 \\
0.93\end{array}$ & & $\begin{array}{l}1.35 \\
1.32 \\
1.30 \\
1.27\end{array}$ & $\begin{array}{r}56 \\
117 \\
116 \\
80\end{array}$ \\
\hline
\end{tabular}

* Weight ${ }^{3} /$ Length 


\section{MOUNTAIN WHITEFISH}

1984

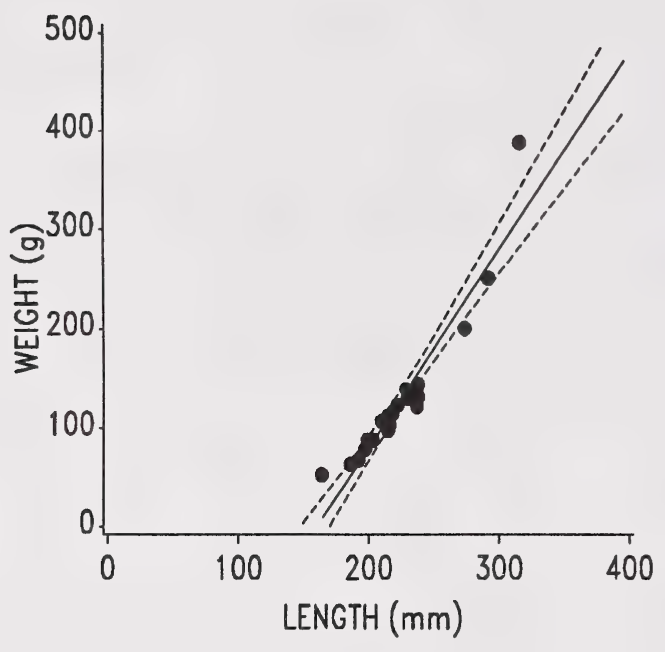

RAINBOW TROUT

1986

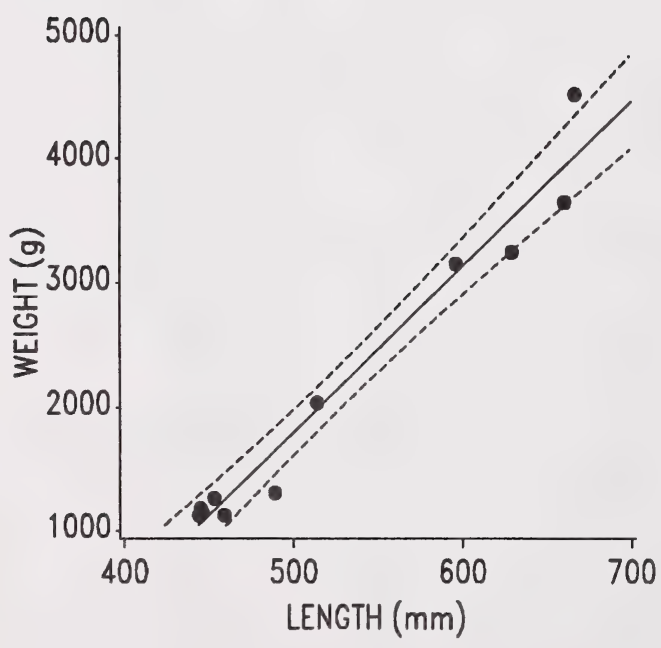

1987

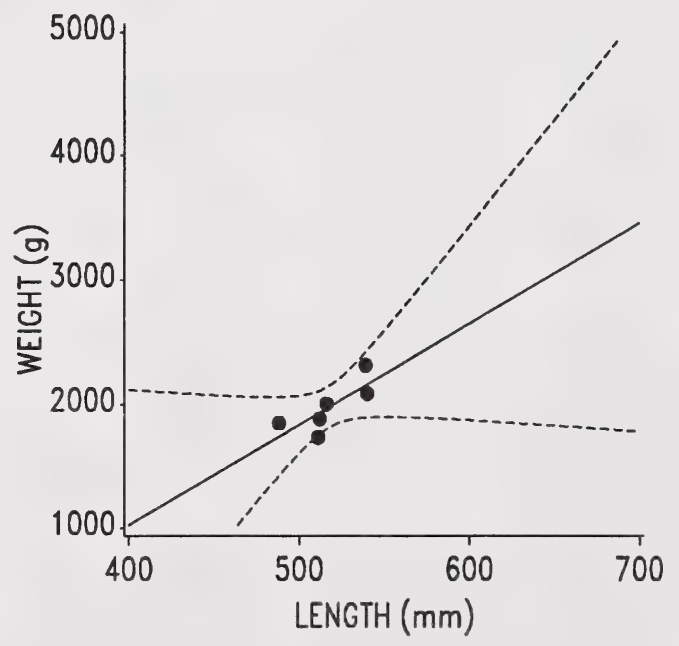

Figure 4. Linear regression analysis $( \pm 95 \%$ confidence limits) relating weight to length of mountain whitefish and rainbow trout collected by gill net from Gleniffer Lake during 1984-87. 
1984

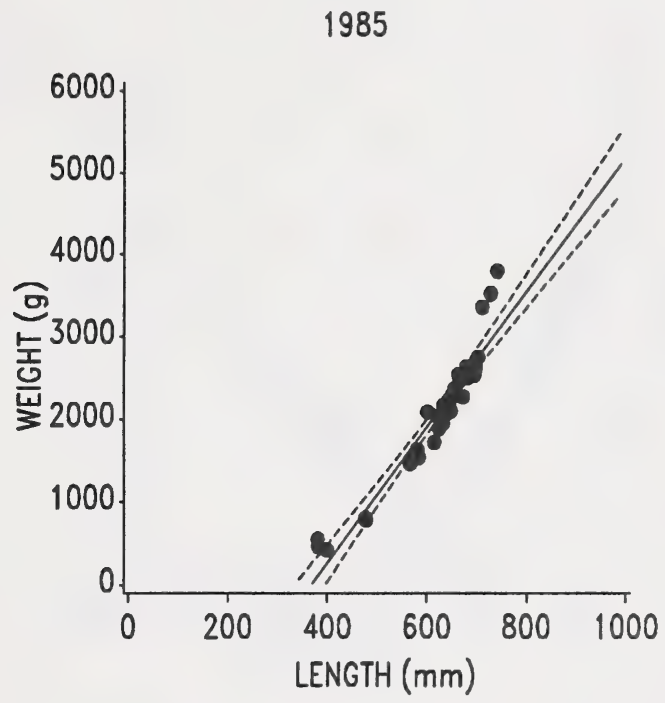

1986
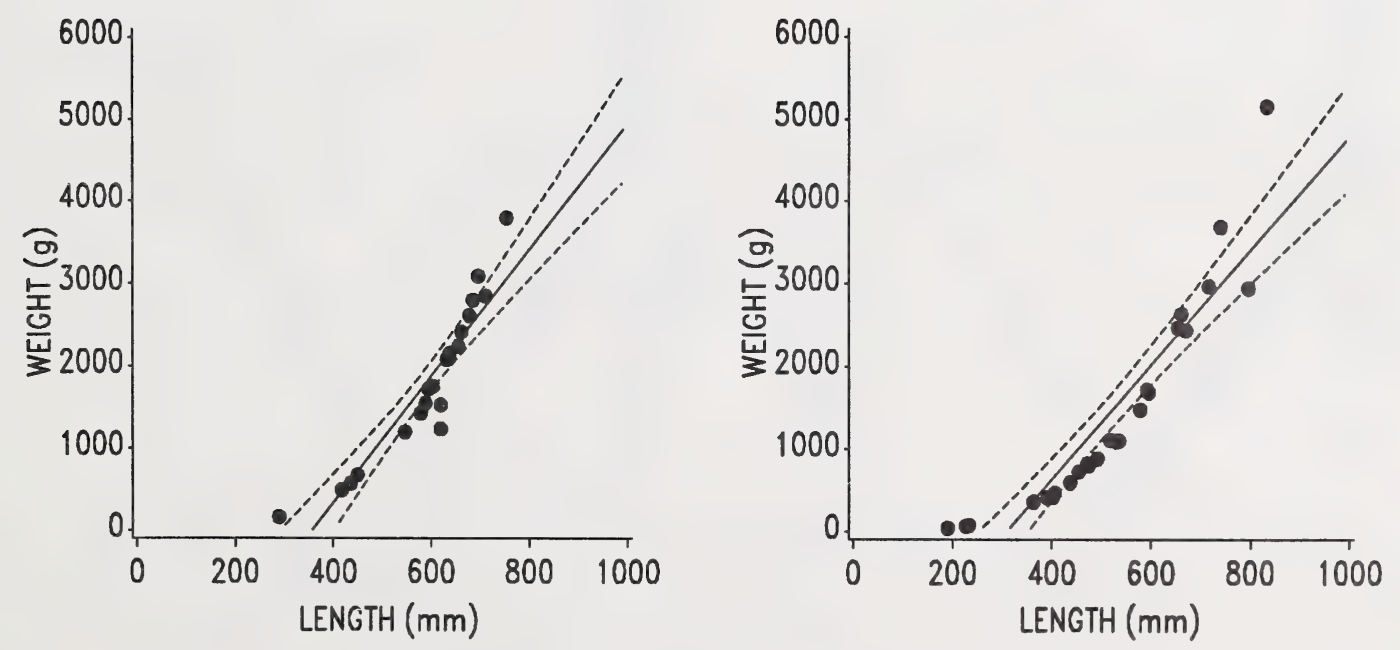

Figure 5. Linear regression analysis ( $\pm 95 \%$ confidence limits) relating weight to length of northern pike collected by gill net from Gleniffer Lake during 1984-87. 
1984

1985
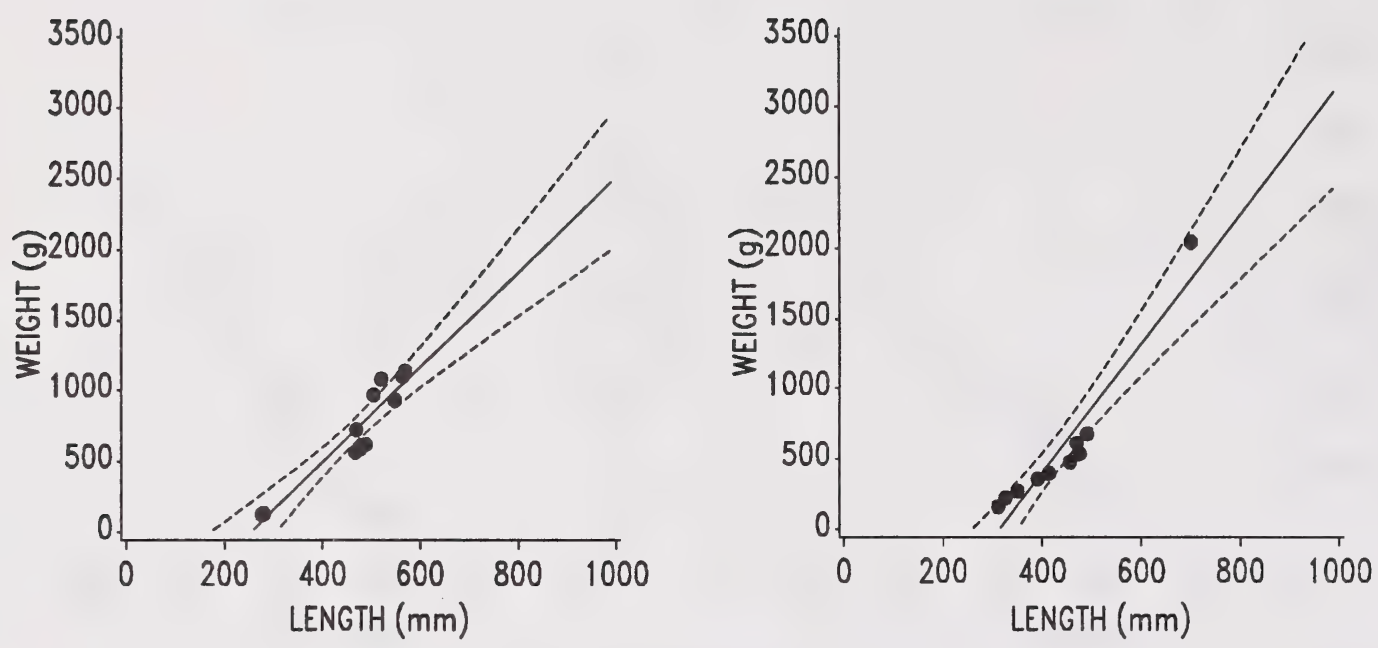

1986

1987
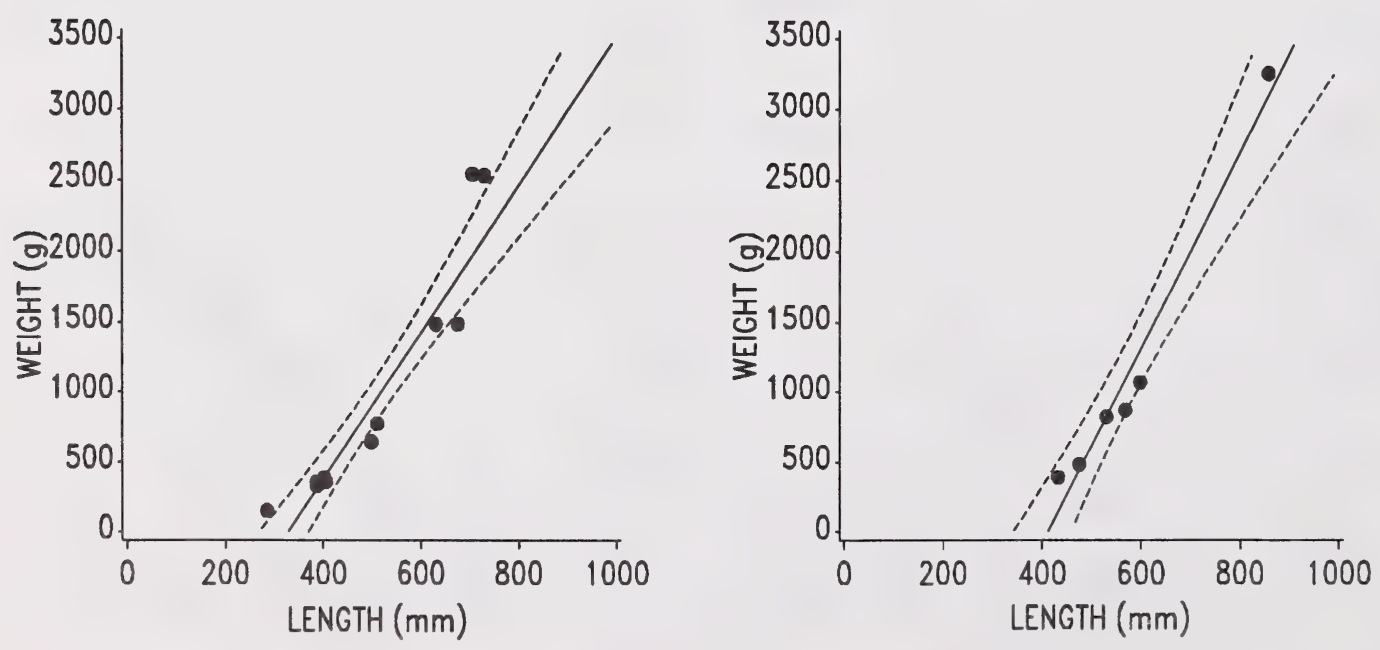

Figure 6. Linear regression analysis ( $\pm 95 \%$ confidence limits) relating weight to length of burbot collected by gill net from Gleniffer Lake during 1984-87. 


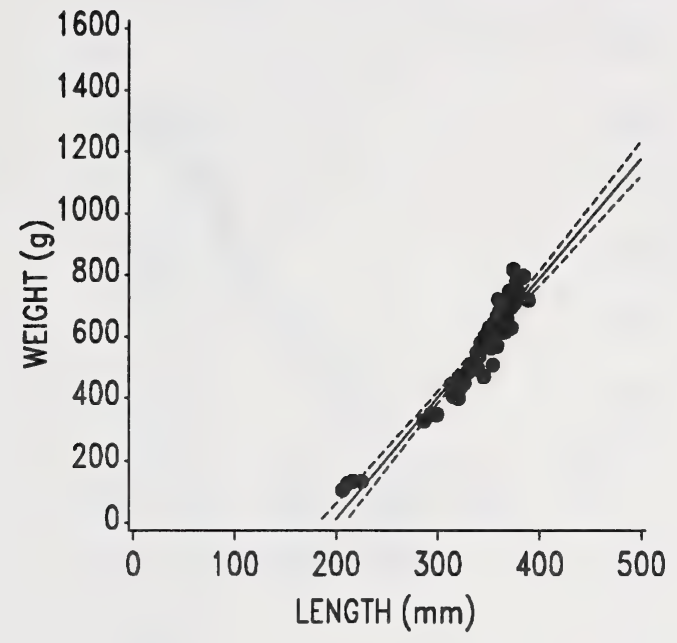

1986

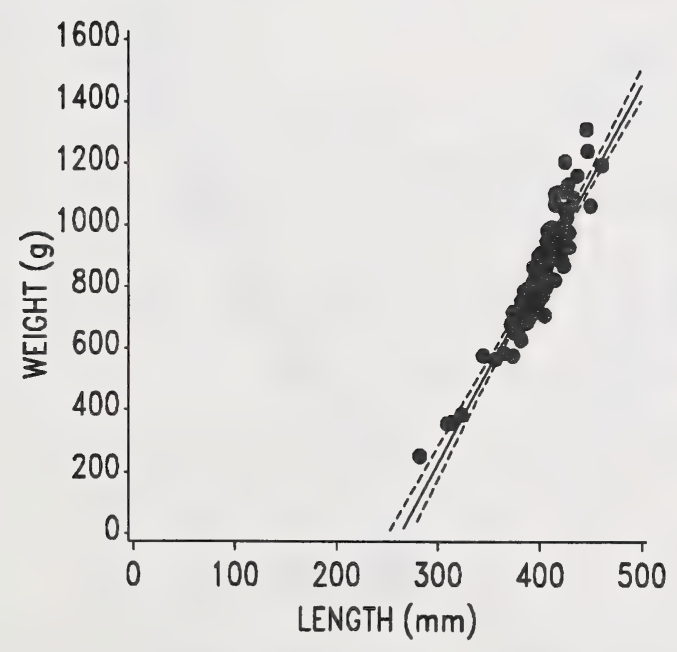

1987

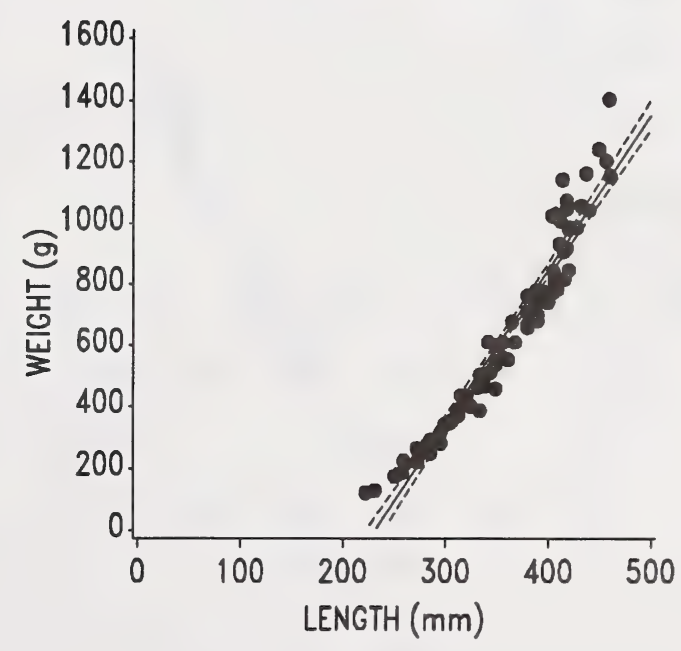

Figure 7 . Linear regression analysis ( $\pm 95 \%$ confidence limits) relating weight to length of longnose sucker collected by gill net from Gleniffer Lake during 1984-87. 


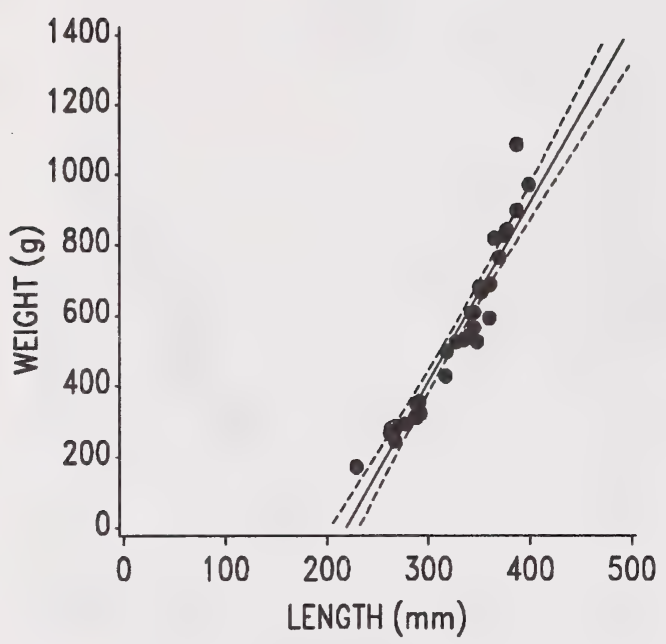

1986

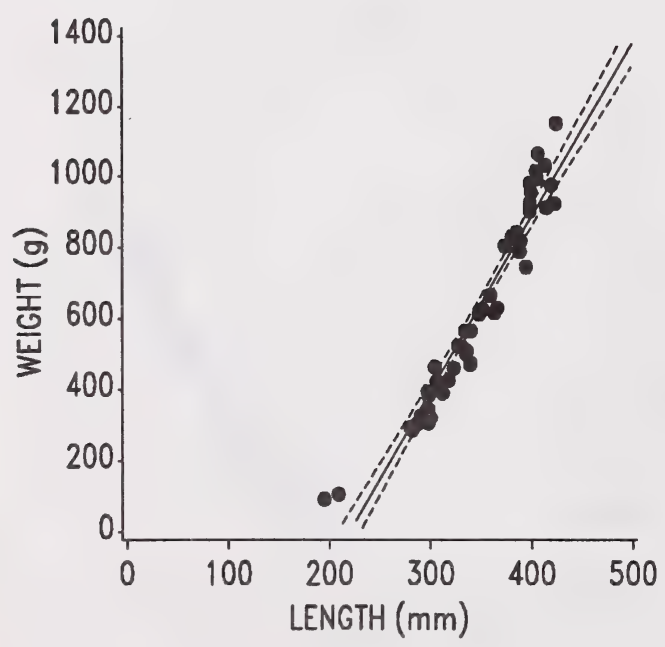

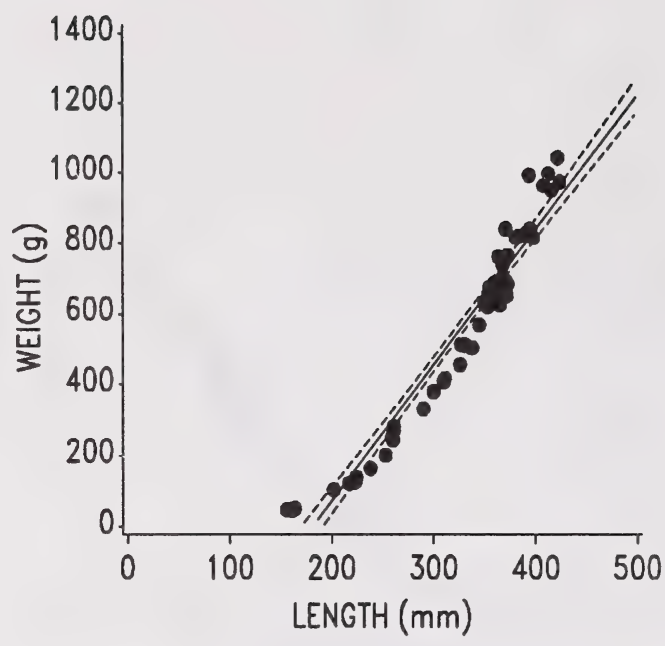

1987

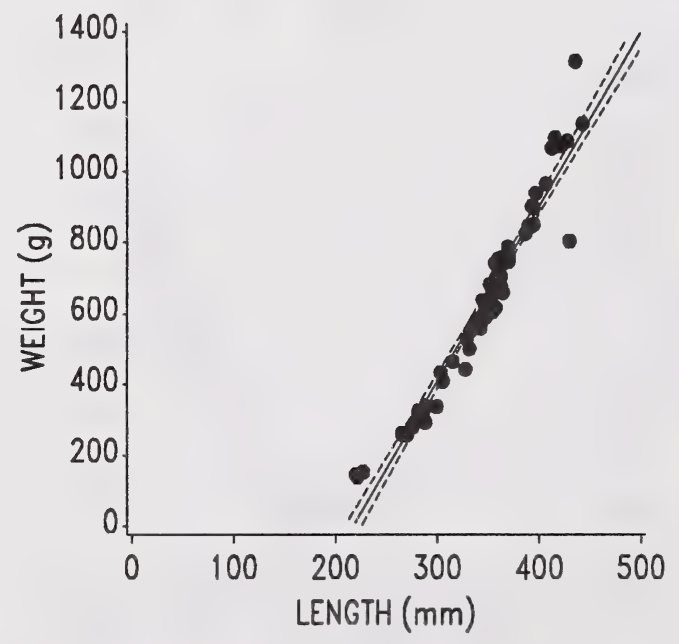

Figure 8. Linear regression analysis ( $\pm 95 \%$ confidence 1 imits) relating weight to length of white sucker collected by gill net from Gleniffer Lake during 1984-87. 
Table 6. t-test of regression slopes relating age to weight for fish caught during 1984, 1985, 1986, and 1987.

\begin{tabular}{|c|c|c|c|}
\hline Species/Year & 1985 & 1986 & 1987 \\
\hline $\begin{array}{l}\text { Rainbow Trout } \\
1986\end{array}$ & & & NS \\
\hline $\begin{array}{l}\text { Northern Pike } \\
1984 \\
1985 \\
1986\end{array}$ & NS & $\begin{array}{l}\text { NS } \\
\text { NS }\end{array}$ & $\begin{array}{l}\text { NS } \\
\text { NS } \\
\text { NS }\end{array}$ \\
\hline $\begin{array}{r}\text { Burbot } \\
1984 \\
1985 \\
1986\end{array}$ & NS & NS & $\begin{array}{l}S \\
S \\
S\end{array}$ \\
\hline $\begin{array}{l}\text { White Sucker } \\
1984 \\
1985 \\
1986\end{array}$ & $S$ & $\begin{array}{r}\text { NS } \\
\text { S }\end{array}$ & $\begin{array}{r}\text { NS } \\
\text { NS }\end{array}$ \\
\hline $\begin{array}{l}\text { Longnose Sucker } \\
1984 \\
1985 \\
1985\end{array}$ & $S$ & $\begin{array}{l}S \\
S\end{array}$ & $\begin{array}{r}S \\
\text { NS } \\
S\end{array}$ \\
\hline
\end{tabular}

$S=$ significant at $P=0.05$

NS= not significant at $P=0.05$

aged (see Discussion). Although the same situation applied to longnose sucker, the relationship between weight and length in white sucker did not change in 1984, 1986 and 1987.

\subsection{Length/Age Relation}

The regression slopes relating age and fork length for fish collected in different years were analyzed using t-test (Tables 7 and 8; Figures 9-13). In the case of longnose sucker, white sucker and northern pike, fish at standard age had a greater fork length in 
Table 7. Regression parameters relating fork length (mm) (independent variable) to age (years) (dependent variable) in fish caught by gill net from Gleniffer Lake during 1984-1987.

\begin{tabular}{|c|c|c|c|c|}
\hline Year & Slope & $Y$-intercept & $r^{2}$ & $N$ \\
\hline & & MOUNTAIN WHITEFISH & & \\
\hline \multirow[t]{2}{*}{1984} & 22.4 & 153 & 0.45 & 24 \\
\hline & & RAINBOW TROUT & & \\
\hline \multirow[t]{2}{*}{$\begin{array}{l}1986 \\
1987\end{array}$} & $\begin{array}{l}73.2 \\
-6.6\end{array}$ & $\begin{array}{l}134 \\
553\end{array}$ & $\begin{array}{l}0.42 \\
0.12\end{array}$ & $\begin{array}{r}11 \\
6\end{array}$ \\
\hline & & NORTHERN PIKE & & \\
\hline $\begin{array}{l}1984 \\
1985 \\
1986 \\
1987\end{array}$ & $\begin{array}{l}13.4 \\
37.7 \\
61.7 \\
68.4\end{array}$ & $\begin{array}{l}446 \\
372 \\
237 \\
170\end{array}$ & $\begin{array}{l}0.05 \\
0.67 \\
0.70 \\
0.94\end{array}$ & $\begin{array}{l}23 \\
35 \\
20 \\
25\end{array}$ \\
\hline 1987 & & BURBOT & & \\
\hline $\begin{array}{l}1984 \\
1985 \\
1986 \\
1987\end{array}$ & $\begin{array}{l}31.1 \\
70.5 \\
45.5 \\
68.8\end{array}$ & $\begin{array}{l}274 \\
107 \\
208 \\
106\end{array}$ & $\begin{array}{l}0.65 \\
0.88 \\
0.31 \\
0.79\end{array}$ & $\begin{array}{r}11 \\
10 \\
13 \\
6\end{array}$ \\
\hline 1987 & & WHITE SUCKER & & \\
\hline $\begin{array}{l}1984 \\
1985 \\
1986 \\
1987\end{array}$ & $\begin{array}{l}31.8 \\
82.9 \\
71.9 \\
53.2\end{array}$ & $\begin{array}{r}217 \\
89 \\
89 \\
135\end{array}$ & $\begin{array}{l}0.61 \\
0.72 \\
0.54 \\
0.74\end{array}$ & $\begin{array}{l}31 \\
54 \\
50 \\
67\end{array}$ \\
\hline 1987 & & LONGNOSE SUCKER & & \\
\hline $\begin{array}{l}1984 \\
1985 \\
1986 \\
1987\end{array}$ & $\begin{array}{l}26.1 \\
31.0 \\
10.5 \\
50.1\end{array}$ & $\begin{array}{l}228 \\
247 \\
353 \\
115\end{array}$ & $\begin{array}{l}0.37 \\
0.44 \\
0.08 \\
0.59\end{array}$ & $\begin{array}{r}56 \\
117 \\
116 \\
80\end{array}$ \\
\hline
\end{tabular}


Table 8. t-test of regression slopes relating age to fork length for fish caught during 1984, 1985, 1986 and 1987.

Rainbow Trout

1986

Northern Pike

1984

1985

NS

NS

$\mathrm{s}$

1986

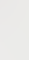

Burbot

1984

1985

S

NS

NS

1986

NS

NS

NS

White Sucker

1984

1985

S S

1986

$\mathrm{S}$

NS

NS

Longnose Sucker

1984

1985

NS

NS

$S$

S

1986

$S=$ significant at $P=0.05$.

$N S=$ not significant at $P=0.05$.

1987 than in 1984. Burbot, on the other hand, showed no significant change in the length/age relationship between 1984 and 1987.

The length/age relationship for rainbow trout was significantly different between 1986 and 1987, presumably reflecting the introduction of hatchery-reared fish of different length. For example, trout aged 3+ years averaged $354 \mathrm{~mm}$ in length in 1986, increasing to $523 \mathrm{~mm}$ in 1987 (Table 9). However, trout decreased in length (from 523 to $513 \mathrm{~mm}$ ) between ages $3+$ and $6+$. 


\section{MOUNTAIN WHITEFISH}

1984
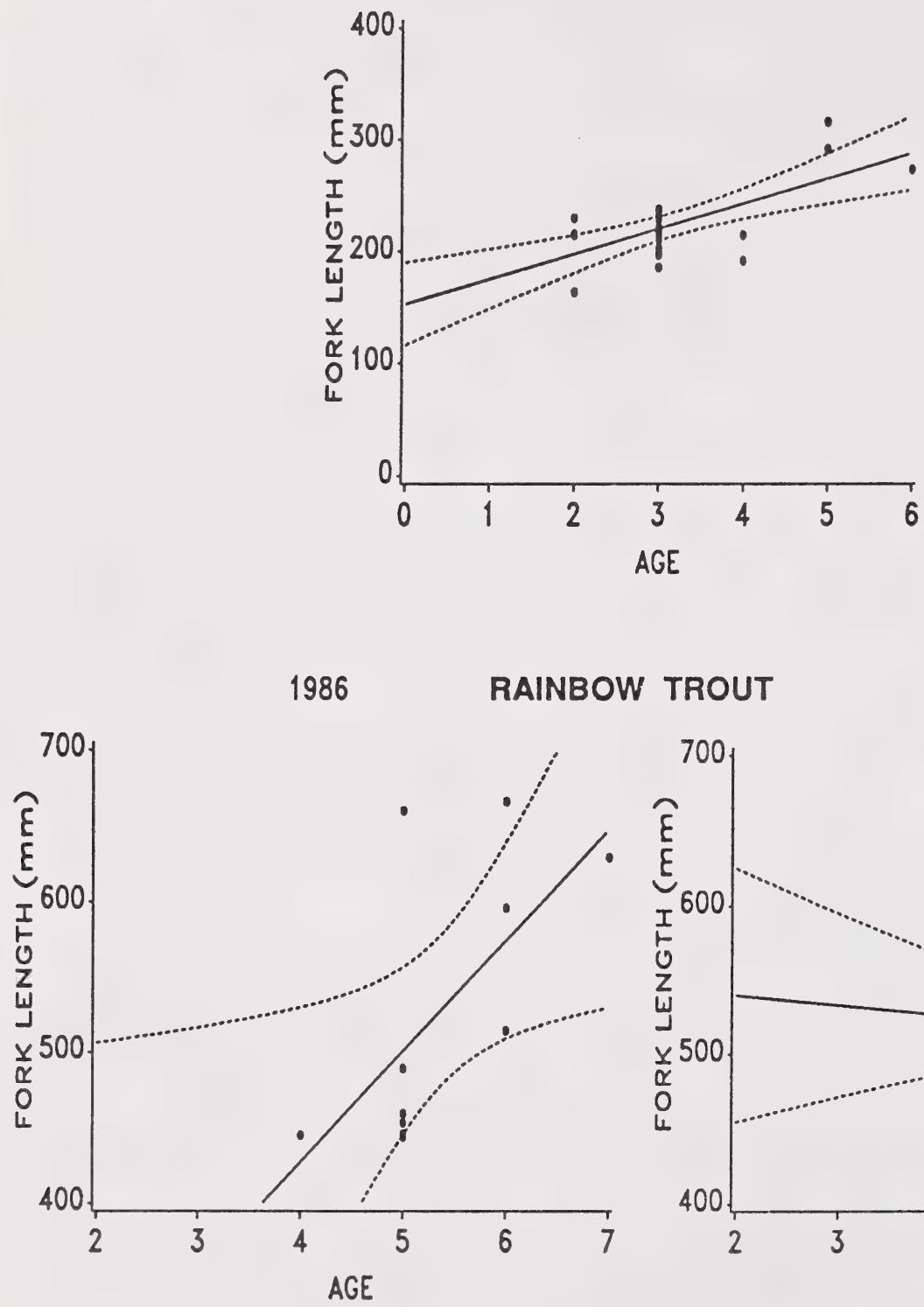

TROUT

1987

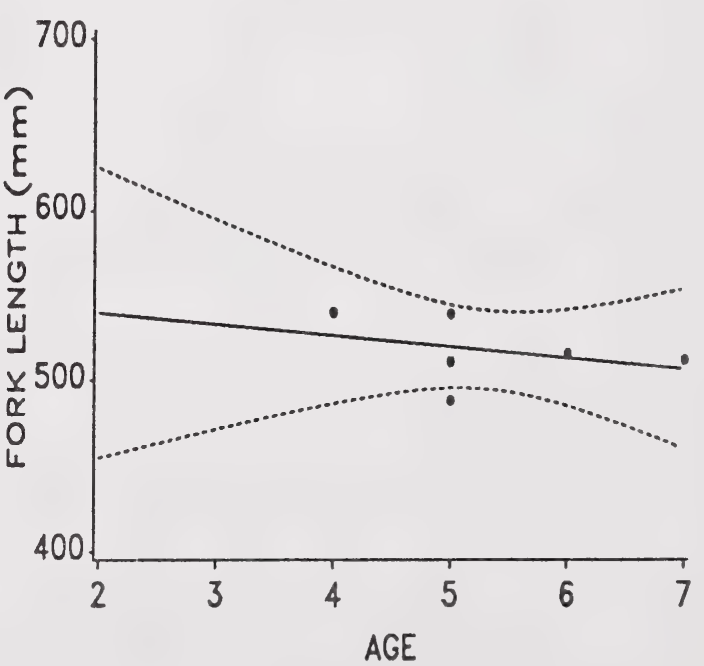

Figure 9. Linear regression analysis $( \pm 95 \%$ confidence limits) relating length to age of mountain whitefish and rainbow trout collected by gill net from Gleniffer Lake during 1984-87. 
1984
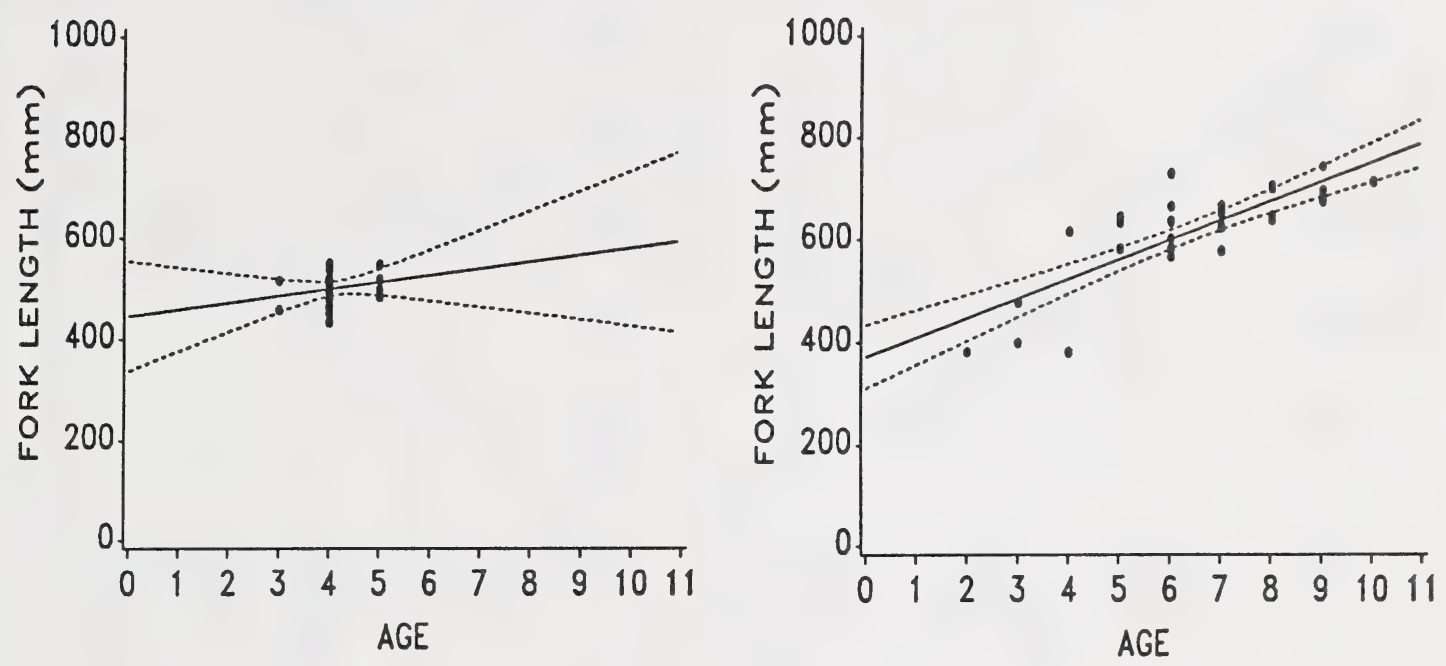

1986

1987
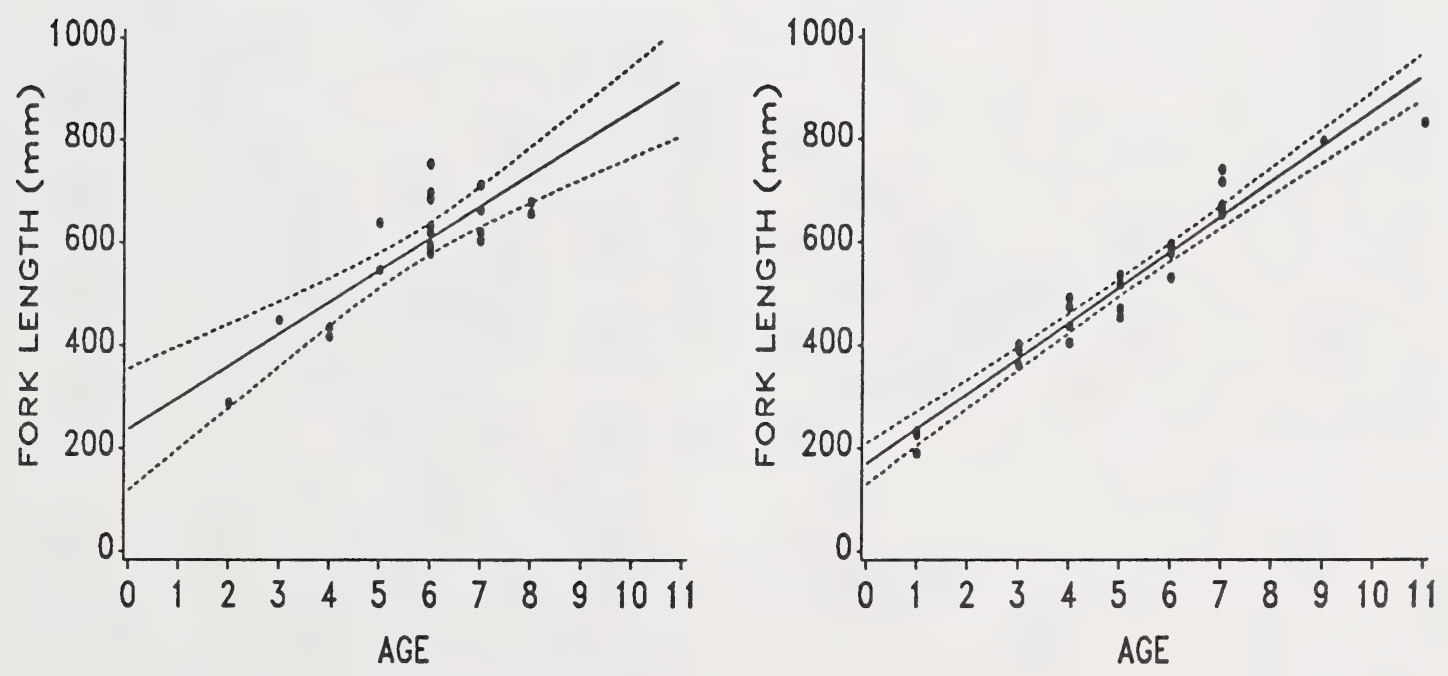

Figure 10. Linear regression analysis ( $\pm 95 \%$ confidence limits) relating length to age of northern pike collected by gill net from Gleniffer Lake during 1984-87. 
1984
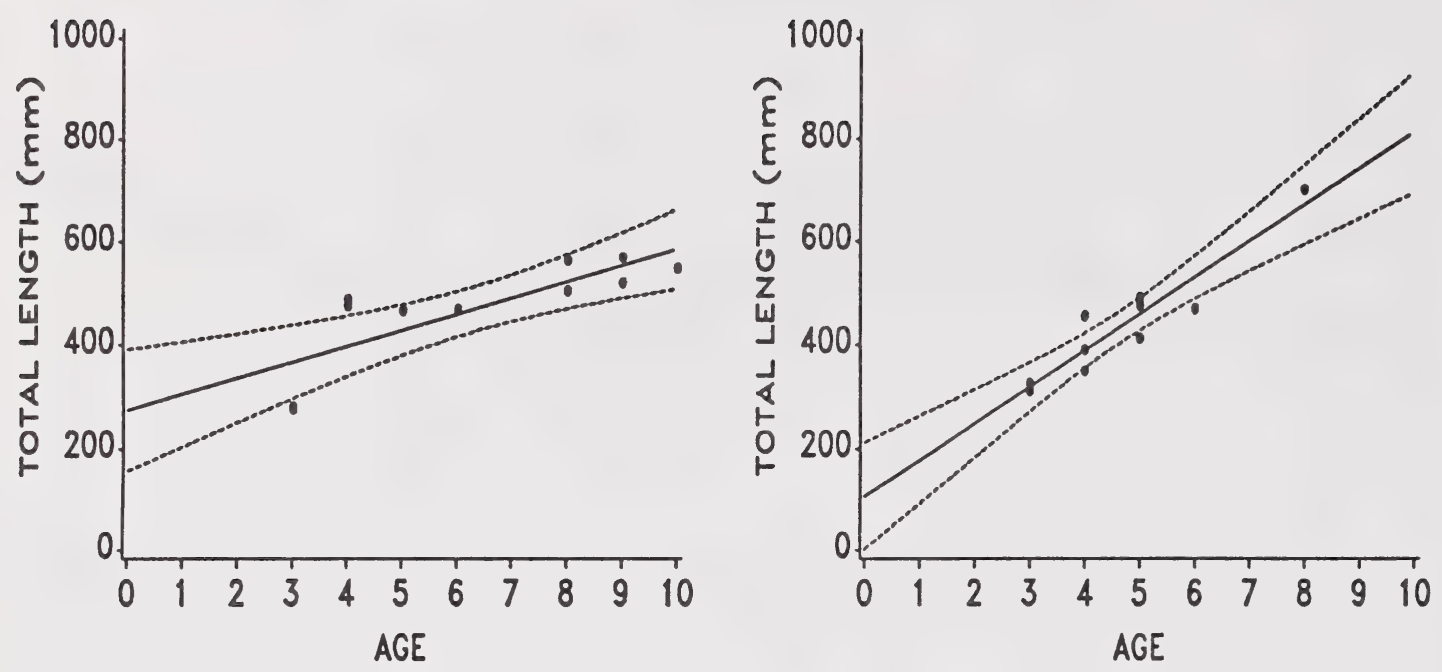

1986
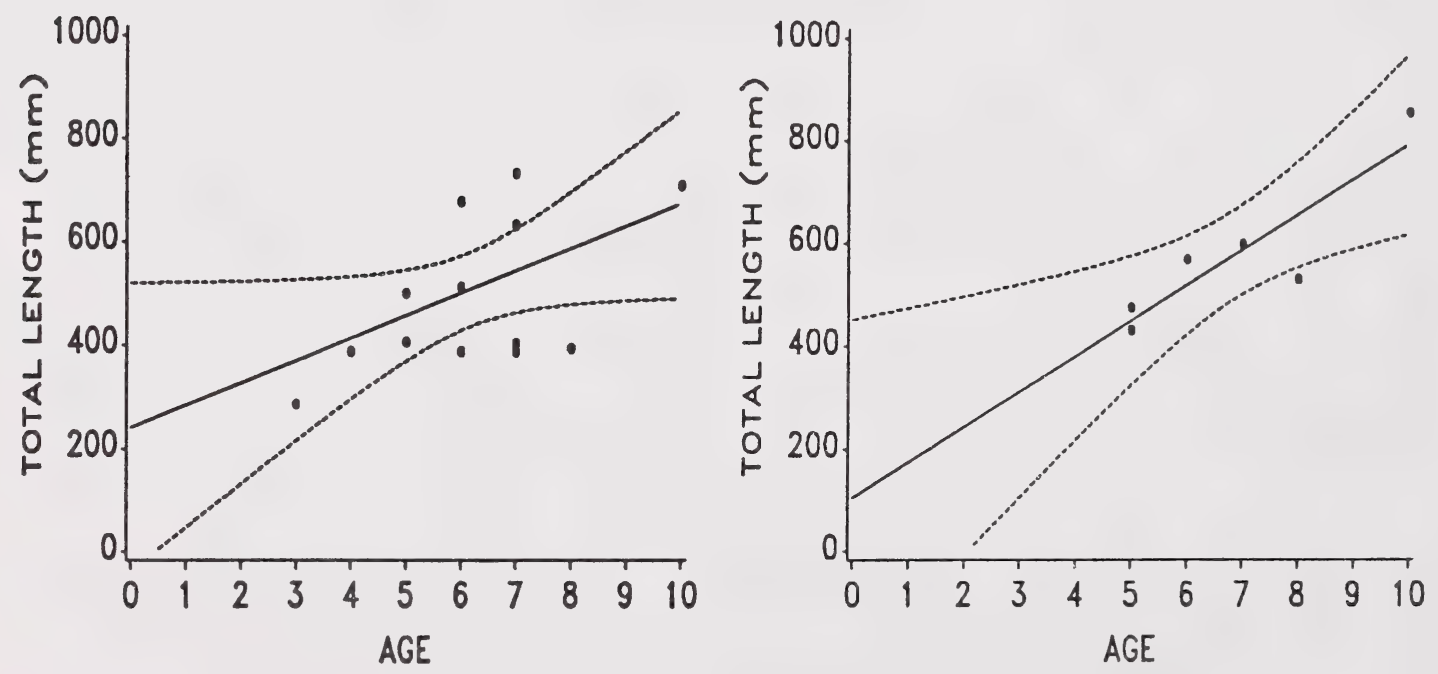

Figure 11. Linear regression analysis ( $\pm 95 \%$ confidence limits) relating length to age of burbot collected by gill net from Gleniffer Lake during 1984-87. 
1984
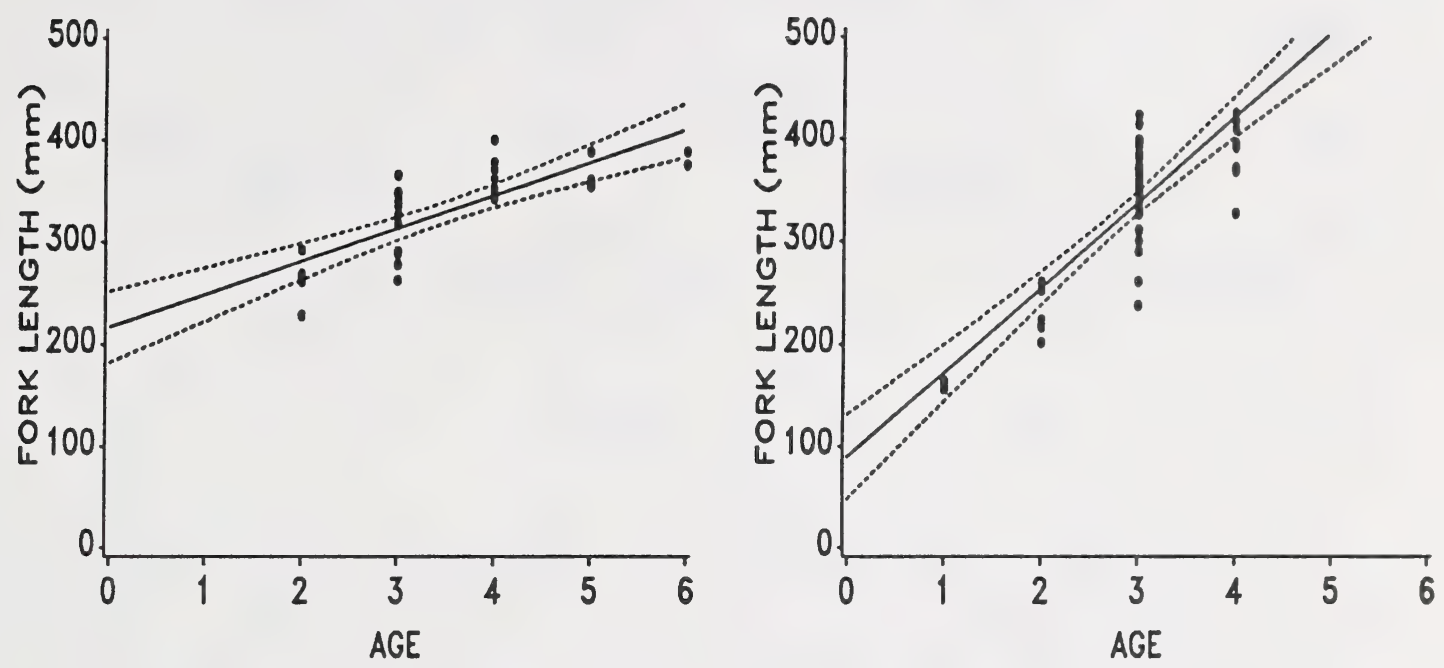

1986
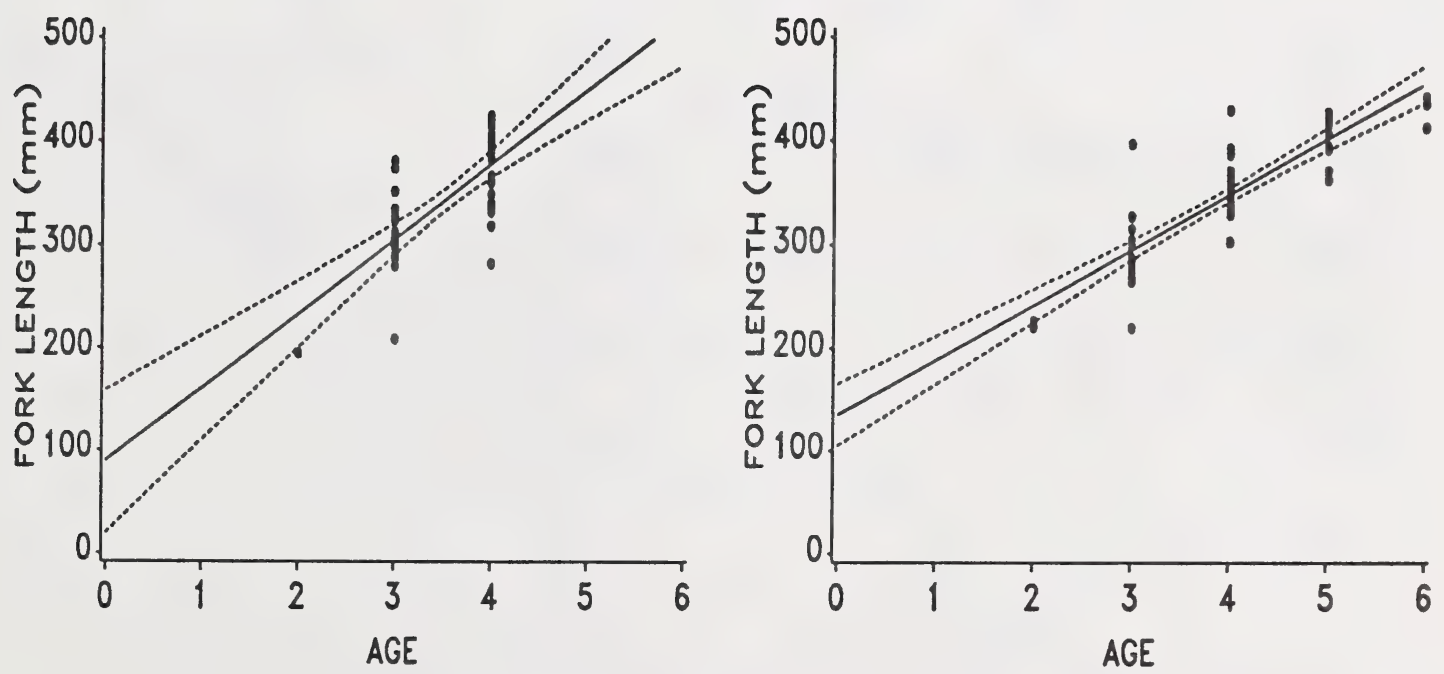

Figure 12. Linear regression analysis ( $\pm 95 \%$ confidence limits) relating length to age of white sucker collected by gill net from Gleniffer Lake during 1984-87. 

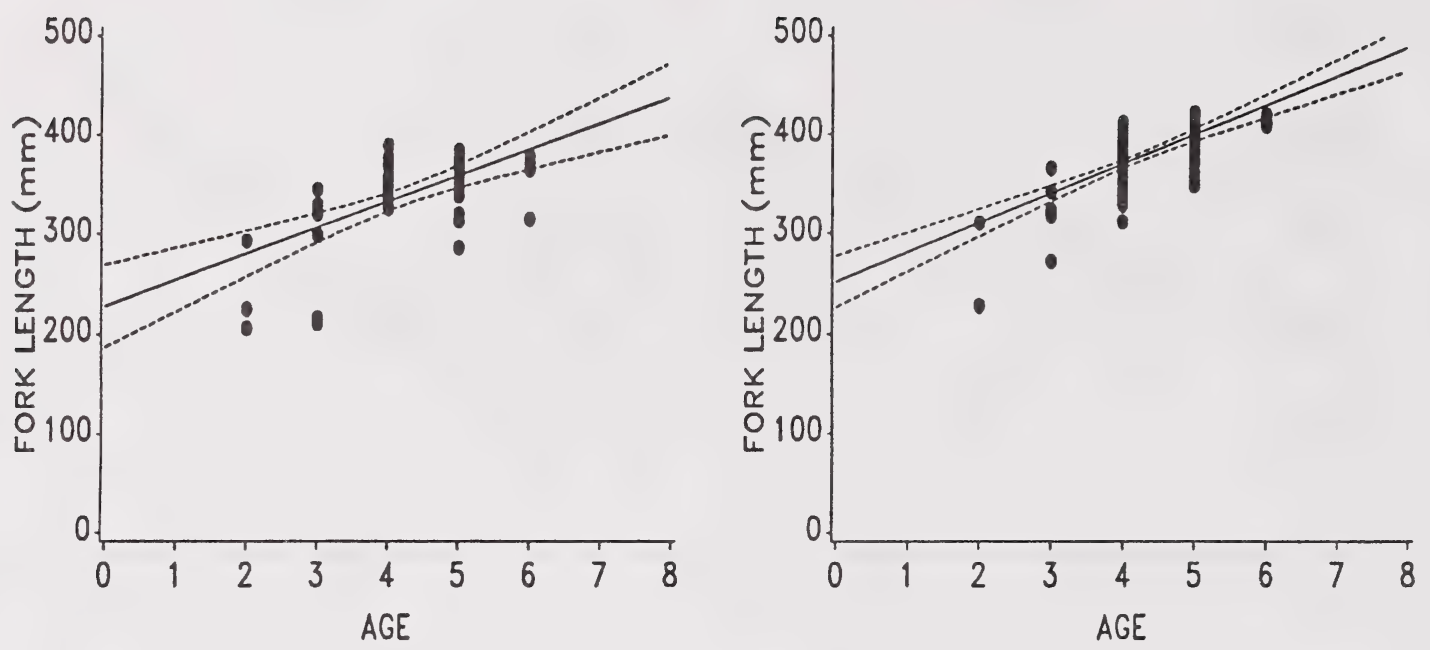

1986
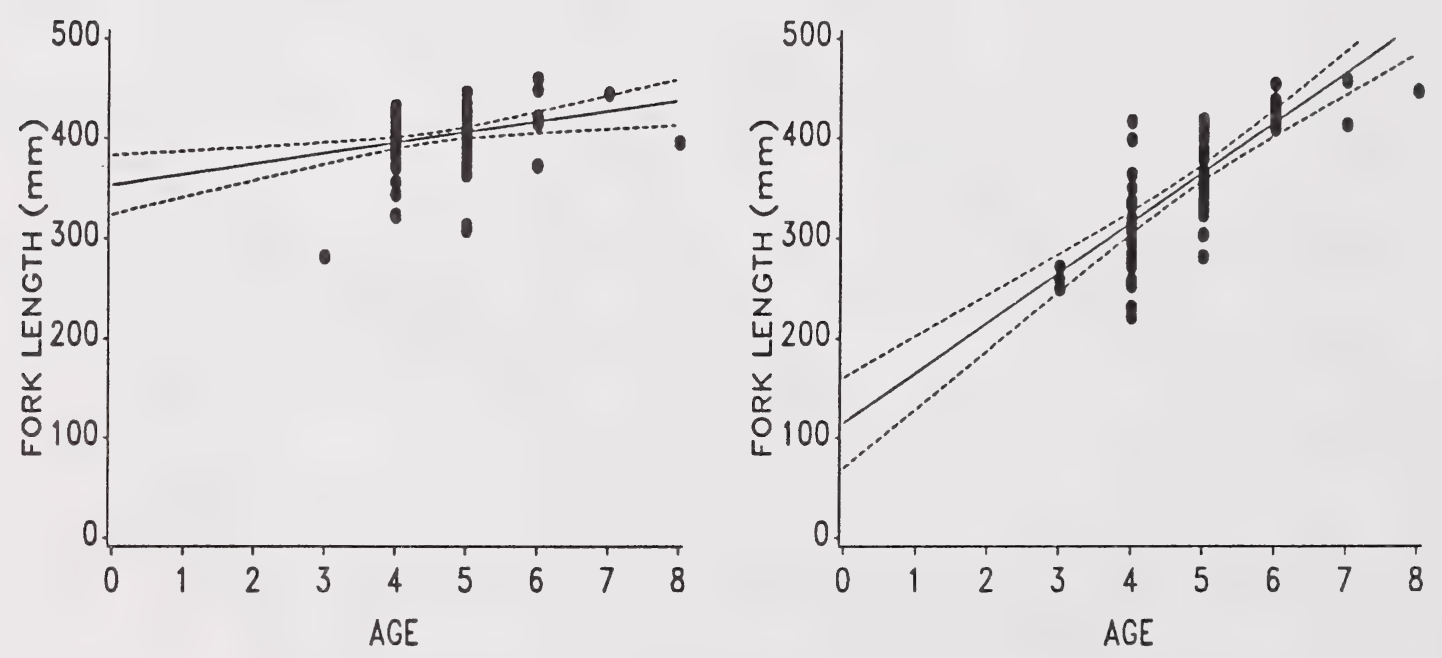

Figure 13. Linear regression analysis ( $\pm 95 \%$ confidence limits) relating length to age of longnose sucker collected by gill net from Gleniffer Lake during 1984-87. 
Table 9. Fork length (mm) of fish of standard age (years) collected by gill net from Gleniffer Lake during 1984-1987.

\section{Standard Age}

\begin{tabular}{|c|c|c|c|c|c|c|c|c|c|c|c|c|}
\hline \multirow{3}{*}{$\begin{array}{l}\text { Year } \\
1984\end{array}$} & $3+$ & $6+$ & $3+$ & $6+$ & $3+$ & $6+$ & $3+$ & $6+$ & $3+$ & $6+$ & $3+$ & $6+$ \\
\hline & \multicolumn{2}{|c|}{$\begin{array}{l}\text { Mountain } \\
\text { Whitefish }\end{array}$} & \multicolumn{2}{|c|}{$\begin{array}{l}\text { Rainbow } \\
\text { Trout }\end{array}$} & \multicolumn{2}{|c|}{$\begin{array}{l}\text { Northern } \\
\text { Pike }\end{array}$} & \multicolumn{2}{|c|}{ Burbot } & \multicolumn{2}{|c|}{$\begin{array}{l}\text { White } \\
\text { Sucker }\end{array}$} & \multicolumn{2}{|c|}{$\begin{array}{l}\text { Longnose } \\
\text { Sucker }\end{array}$} \\
\hline & 220 & 287 & ND & ND & 486 & 526 & 367 & 461 & 312 & 408 & 306 & 384 \\
\hline 1985 & ND & ND & ND & ND & 485 & 598 & 318 & 530 & 338 & 586 & 340 & 433 \\
\hline 1986 & ND & ND & 354 & 573 & 422 & 607 & 344 & 481 & 305 & 520 & 385 & 417 \\
\hline 1987 & ND & ND & 523 & 513 & 375 & 580 & 312 & 520 & 295 & 454 & 265 & 415 \\
\hline
\end{tabular}

ND $=$ no data

\subsection{Stomach Contents}

\subsubsection{Mountain Whitefish}

This species, collected only in 1984, fed mainly on cladocerans (Daphnia sp.) and insects (Table 10). The cladoceran component accounted for $95-99 \%$ of the dry weight of stomach contents, which ranged from 0.03 to $0.31 \mathrm{~g}$ dry weight per fish.

\subsubsection{Rainbow Trout}

Although rainbow trout were captured in all years, detailed stomach analysis was limited to the 1986 and 1987 collections, which included a relatively large number of specimens. In both years, insects were present in the stomachs of most fish (Table 10), whereas 
plant material and unidentified remains were also found in many stomachs. The total weight of stomach contents ranged from $0.01 \mathrm{~g}$ to $5.5 \mathrm{~g}$ dry weight per fish.

\subsubsection{Northern Pike}

The majority of stomachs of northern pike collected in 1985 and 1986 were empty (Tables 10 and 11). In 1984 and 1987, however, fish and unidentified remains were found in the majority of stomachs. The most frequently consumed fish were stickleback (Gasterosteus sp.), sucker (unidentified) and mountain whitefish (Prosopium williamsoni) (only in 1984) (Tables 10 and 11). Only one rainbow trout was found in the pike stomachs. Weight of stomach contents ranged from $0.0 \mathrm{~g}$ to $20.4 \mathrm{~g}$ dry weight per fish.

\subsubsection{Burbot}

Burbot were also piscivorous - approximately $45 \%$ of all stomach examined contained fish (Tables 10 and 11). The most frequently ingested species was stickleback (unidentified). Insects were also numerically important (Table 10) but, in terms of weight, formed $<1 \%$ of ingested material (Table 10). Weight of stomach contents ranged from $0.0 \mathrm{~g}$ to $5.4 \mathrm{~g}$ dry weight per fish.

\subsection{Fecundity}

Based on the regression parameters in Table 12, burbot of standard fork length $(600 \mathrm{~mm})$ contained approximately $774 \times 10^{3}$ eggs/fish. 
Table 10. Summary of stomach content analyses.

Number of Stomachs Containing Item

Year Number of Fish Fish Insects Cladocerans Molluscs $\begin{gathered}\text { Unidentified } \\ \text { Remains }\end{gathered}$

MOUNTAIN WHITEFISH

\begin{tabular}{|c|c|c|c|c|c|c|}
\hline 1984 & 45 & 0 & 25 & 31 & 0 & 12 \\
\hline \multicolumn{7}{|c|}{ RAINBOW TROUT } \\
\hline $\begin{array}{l}1986 \\
1987\end{array}$ & $\begin{array}{r}17 \\
8\end{array}$ & $\begin{array}{l}0 \\
0\end{array}$ & $\begin{array}{r}12 \\
8\end{array}$ & $\begin{array}{l}1 \\
1\end{array}$ & $\begin{array}{l}1 \\
4\end{array}$ & $\begin{array}{l}8 \\
7\end{array}$ \\
\hline \multicolumn{7}{|c|}{ NORTHERN PIKE } \\
\hline $\begin{array}{l}1984 \\
1985 \\
1986 \\
1987\end{array}$ & $\begin{array}{l}25 \\
35 \\
20 \\
25\end{array}$ & $\begin{array}{r}13 \\
8 \\
2 \\
11\end{array}$ & $\begin{array}{l}4 \\
0 \\
0 \\
0\end{array}$ & $\begin{array}{l}1 \\
0 \\
0 \\
0\end{array}$ & $\begin{array}{l}0 \\
0 \\
0 \\
0\end{array}$ & $\begin{array}{r}6 \\
0 \\
0 \\
10\end{array}$ \\
\hline \multicolumn{7}{|c|}{ BURBOT } \\
\hline $\begin{array}{l}1984 \\
1985 \\
1986 \\
1987\end{array}$ & $\begin{array}{r}12 \\
11 \\
13 \\
6\end{array}$ & $\begin{array}{l}5 \\
5 \\
6 \\
3\end{array}$ & $\begin{array}{l}5 \\
4 \\
5 \\
2\end{array}$ & $\begin{array}{l}0 \\
1 \\
0 \\
0\end{array}$ & $\begin{array}{l}1 \\
0 \\
0 \\
1\end{array}$ & $\begin{array}{l}2 \\
3 \\
5 \\
1\end{array}$ \\
\hline
\end{tabular}

Northern pike of the same length contained $48 \times 10^{3}$ eggs/fish. The corresponding number of eggs/fish for rainbow trout $(500 \mathrm{~mm})$, longnose sucker $(400 \mathrm{~mm})$ and white sucker $(400 \mathrm{~mm})$ is $4300,32,200$ and 43,700 respectively. In all species, the number of eggs increased with the length of the fish (Figure 14). 


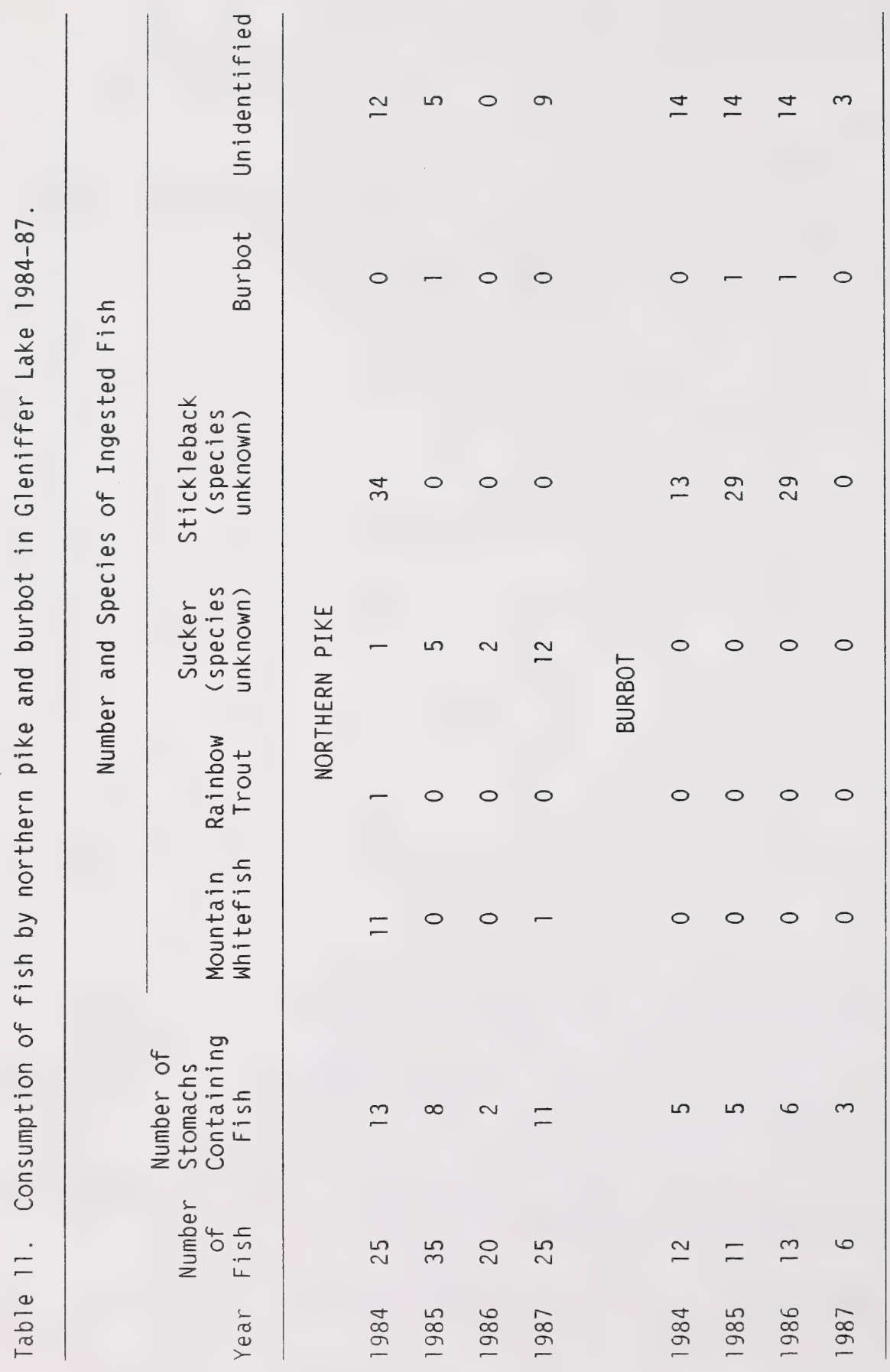


BURBOT

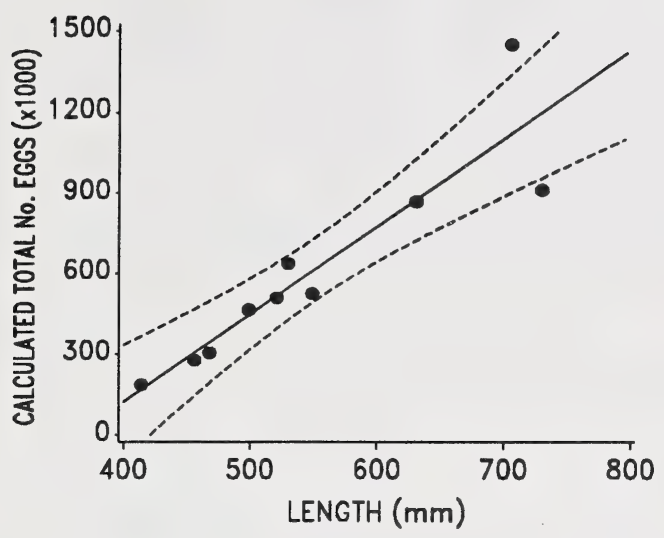

NORTHERN PIKE

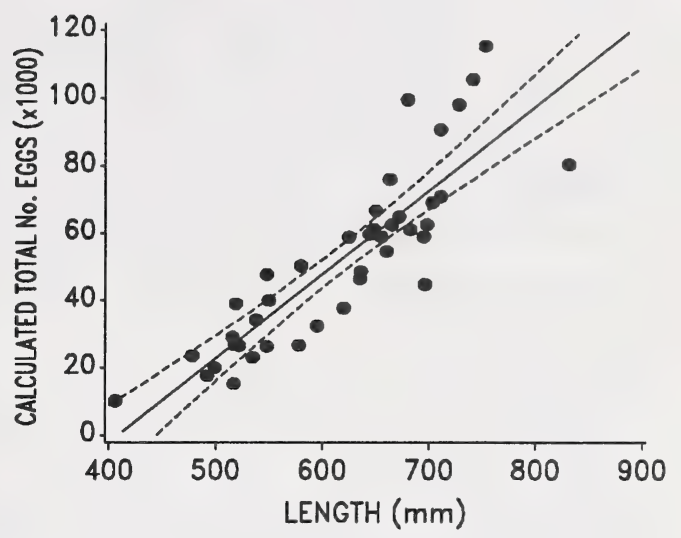

RAINBOW TROUT

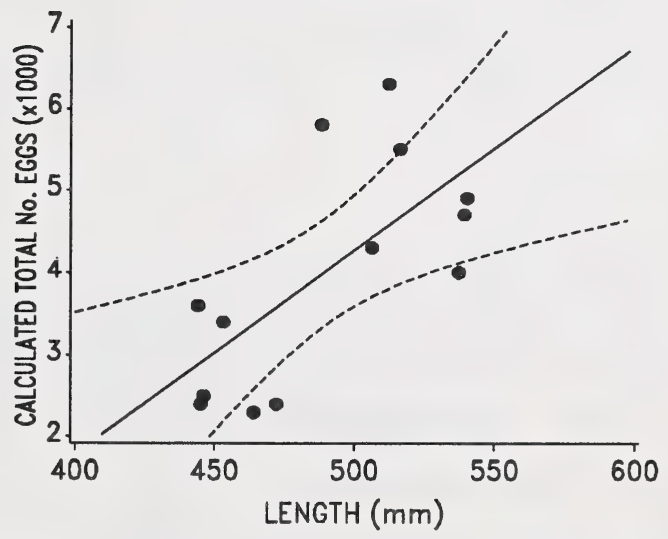

LONGNOSE SUCKER

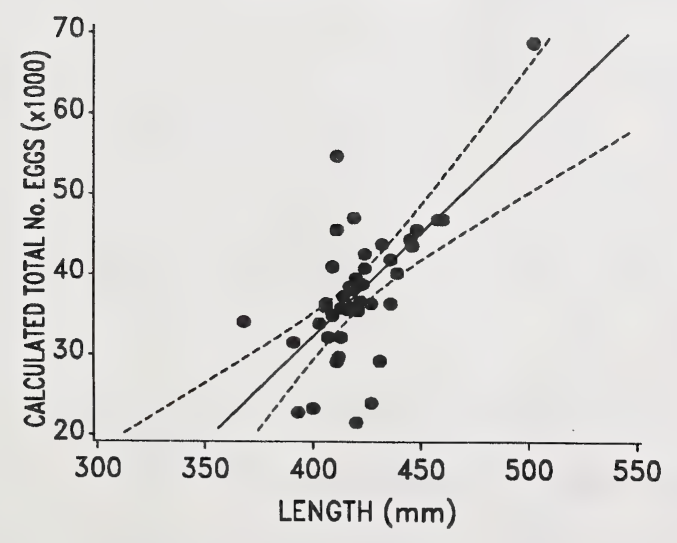

WHITE SUCKER

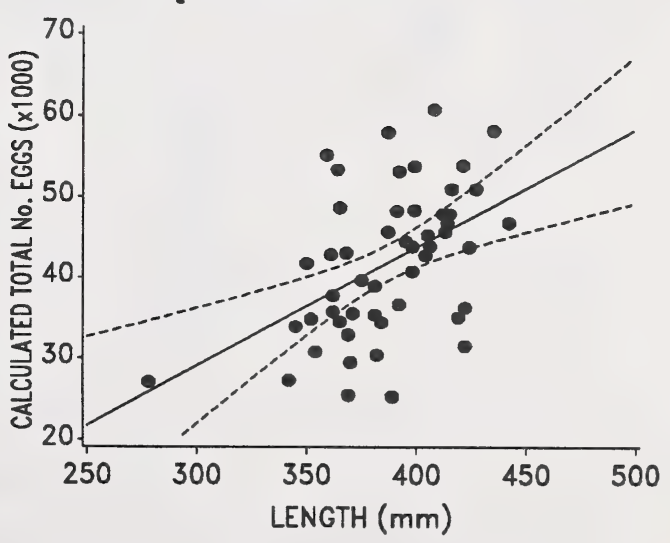

Figure 14. Linear regression analysis ( $\pm 95 \%$ confidence 1 imits) relating length to calculated total number of eggs of burbot, northern pike, rainbow trout, longnose sucker and white sucker collected by gill net from Gleniffer Lake during 1984-87. 
Table 12. Regression parameters relating length (mm) to calculated total number of eggs in fish caught by gill net from Gleniffer Lake during 1984-1987.

\begin{tabular}{lcccc}
\hline Species & Slope & Y-intercept & $r^{2}$ & $N$ \\
\hline Rainbow Trout & 24.9 & $-8,154$ & 0.46 & 13 \\
Northern Pike & 248.9 & $-101,500$ & 0.76 & 41 \\
Burbot & 3250 & $-1,176,100$ & 0.84 & 10 \\
White Sucker & 145.9 & $-14,649$ & 0.29 & 51 \\
Longnose Sucker & 259.0 & $-71,449$ & 0.42 & 42 \\
\hline
\end{tabular}

5. DISCUSSION

Mountain whitefish apparently were trapped by impoundment of the Red Deer River in 1983. Although inhabiting the reservoir for another year, the population either died out or emigrated from the reservoir by 1985. This is typical of whitefish populations in other parts of Canada. For example, Bodaly et al. (1984) attributed the post-impoundment collapse of the lake whitefish (Coregonus clupeaformis) to emigration from the reservoir. Similarly, increased sedimentation in reservoirs reduces the rate of survival of lake whitefish eggs (Fudge and Bodaly, 1984).

Because mountain whitefish could have spent no more than 1 year in the reservoir prior to capture in 1984, most of their growth was due to life in the river rather than the reservoir. These whitefish were 
relatively large compared to lake-dwelling fish, but were slightly smaller than those from the North Saskatchewan River (Table 13). No comparative records appear to be available regarding growth of mountain whitefish in the Red Deer River upstream of the reservoir.

Because rainbow trout of different age and size were planted in Gleniffer Lake, reliable determinations of growth after release cannot be made. In 1986, for example, the average fork length of 3+ years trout was $343 \mathrm{~mm}$ whereas, in 1987, the corresponding length was $523 \mathrm{~mm}$. This reflects the planting of relatively large hatchery reared fish in the 1984-year class. In comparison to other lakes, the

Table 13. Mean fork length $(\mathrm{mm})$ of mountain whitefish at age $3+$ and $6+$ years in various lakes and rivers.

\begin{tabular}{|c|c|c|c|}
\hline \multirow[b]{2}{*}{ Lake/River } & \multicolumn{2}{|c|}{ Age (Years) } & \multirow[b]{2}{*}{ Reference } \\
\hline & $3+$ & $6+$ & \\
\hline $\begin{array}{l}\text { Gleniffer Lake, } A B \\
\text { Bow Lake, } A B \\
\text { Pyramid Lake, } A B \\
\text { Kananaskis Lake, } A B \\
\text { Waterton Lake, } A B \\
\text { Lake Minnewanka, } A B \\
\text { Ghost River Reservoir, } A B \\
\text { Cultus Lake, } B C \\
\text { North Saskatchewan River, } A B\end{array}$ & $\begin{array}{l}220 \\
104 \\
150 \\
171 \\
171 \\
171 \\
199 \\
218 \\
247\end{array}$ & $\begin{array}{r}287 \\
142 \\
268 \\
267 \\
260 \\
273 \\
\text { NR } \\
305 \\
334\end{array}$ & $\begin{array}{c}\text { This study } \\
1 \\
2 \\
1 \\
1 \\
1 \\
1 \\
1 \\
3\end{array}$ \\
\hline
\end{tabular}

SOURCES: 1. MCHugh (1941)

2. Rawson and Elsey (1948)

3. Alberta Forestry, Lands and Wildlife (1989)

$N R=$ not reported 
trout planted in Gleniffer Lake were relatively large at age 3+ years (Table 14), but this reflects a combination of growth in the hatchery and reservoir.

Northern pike which were $3+$ years old and caught in 1984 must have been spawned in 1981 and presumably spent the first 2-3 years of their life in the Red Deer River. On the other hand, pike of the same age

Table 14. Mean fork length $(\mathrm{mm})$ of rainbow trout at age $3+$ and $6+$ years in various lakes.

Age (Years)

Lake

$3+$

$6+$

Reference

Gleniffer, $A B$ (1986)

354

523

190

Pyramid, $A B$

290

Okanagan, BC

303

Watch, BC

291

Cluculz, BC

275

Lightning, $B C$

183

Pennask, BC

Loon, BC

203

Bouche, $B C$

213

Big Bar, BC

222

Kelly, BC

Beaver, $B C$

252

Dairy, $B C$

257

Knouff, BC

354

Pavilion, $B C$

356

Glimpse, $B C$

380

Peterhope, $B C$

468

573
513
376
$N R$
590
$N R$
NR
NR
NR
NR
NR
NR
NR
NR
NR
NR
NR
NR
NR

This study

This study

376

NR

590

NR

NR

NR

NR

NR

NR

NR

NR

NR

NR

NR

NR

NR

NR

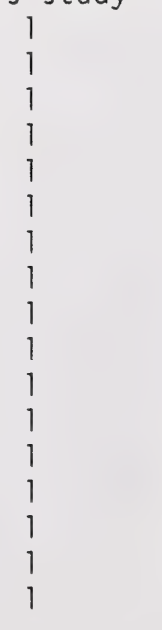

SOURCE: 1. Larkin et al. (1956)

$N R=$ not reported 
captured in 1987 were spawned in 1984 and had presumably spent all of their life in the reservoir. From Table 15, it is apparent that the 1987-caught fish were much smaller than the 1984-caught fish, implying that the river provided better habitat for the growth of young pike than the reservoir. The specific factors influencing the difference in growth are not known at this time. From age $3+$ to $6+$ years, pike grew much faster in the reservoir than the river (Table 15). It is possible that impoundment of the river significantly curtailed the production of fry and other potential food fish for young pike. As the reservoir matured, however, reproduction of potential food species increased. Rainbow trout, introduced in large numbers to the reservoir, was not a significant food of northern pike.

Fork length of northern pike at age $6+$ years was comparable to fish from many other Alberta lakes (Table 15). For comparison the age 3+ pike caught in 1987 from the reservoir were shorter than fish from 10 other lakes listed in Table 15. Once again, the factors influencing the differences in growth are not known.

The growth of burbot was largely unaffected by impoundment, with the apparent exception of 1984-1985. During that period, the regression slopes relating length to age changed significantly: $3+$ year old fish caught in 1985 were smaller than those caught in 1984 while 6+ year old burbot were larger in 1985 than 1984. As with northern pike, it appears that the river provided better habitat for the growth of young burbot whereas the reservoir was better for the growth of older burbot. This trend was not apparent in subsequent 
Table 15. Mean fork length (mm) of northern pike at age $3+$ and $6+$ years in various Alberta lakes.

\begin{tabular}{|c|c|c|c|}
\hline \multirow[b]{2}{*}{ Lake } & \multicolumn{2}{|c|}{ Age (Years) } & \multirow[b]{2}{*}{ Reference } \\
\hline & $3+$ & $6+$ & \\
\hline $\begin{array}{l}\text { Gleniffer (1984) } \\
\text { Gleniffer (1985) } \\
\text { Gleniffer (1986) } \\
\text { Gleniffer (1987) } \\
\text { Amisk } \\
\text { Beaver } \\
\text { Cold } \\
\text { Elinor } \\
\text { Garner } \\
\text { Lac La Biche } \\
\text { Lac Ste. Anne } \\
\text { Muriel } \\
\text { Pinehurst } \\
\text { Touchwood }\end{array}$ & $\begin{array}{l}486 \\
485 \\
422 \\
375 \\
431 \\
488 \\
463 \\
411 \\
508 \\
476 \\
385 \\
490 \\
464 \\
431\end{array}$ & $\begin{array}{r}526 \\
598 \\
607 \\
580 \\
N R \\
561 \\
635 \\
485 \\
571 \\
666 \\
N R \\
595 \\
601 \\
591\end{array}$ & $\begin{array}{c}\text { This study } \\
\text { This study } \\
\text { This study } \\
\text { This study } \\
1 \\
1 \\
1 \\
1 \\
1 \\
1 \\
1 \\
1 \\
1 \\
1\end{array}$ \\
\hline
\end{tabular}

SOURCE: 1. Alberta Forestry, Lands and Wildlife (1983-1986) $N R=$ not reported

years (Table 7). The overall growth of burbot in the reservoir was intermediate between populations in northern and more temperate lakes (Table 16).

White sucker and longnose sucker grew significantly faster in the reservoir than in the river (Tables 7,8 ). The older fish were most affected whereas young suckers showed no increase in growth. As with northern pike, it appears that the absence of a good food base during the first years of impoundment limited growth. Suckers feed primarily on benthic invertebrates, a group of organisms that would be virtually 
Table 16. Mean fork length (mm) of burbot at age $3+$ and $6+$ years in various lakes.

Age (Years)

Lake

$3+$

$6+$

Reference

Gleniffer, $A B$ (1984)

Gleniffer, $A B$ (1985)

Gleniffer, $A B$ (1986)

Gleniffer, $A B$ (1987)

Heming, MN

Superior, WI

Erie, ON

Simcoe, ON

WI

$$
\text { ON }
$$

\section{SOURCES: 1. Scott and Crossman (1973) \\ 2. Becker (1983)}

eliminated during reservoir construction but which could rapidiy recolonize the substrate. This reflects the ability of many invertebrate species such as insects to complete their life cycle in $<1$ year and to move long distances. Sucker growth in the reservoir was relatively rapid, even when compared to populations in more temperate climates (Tables 17,18 ).

Since only one rainbow trout was found in the stomachs of 34 northern pike from the reservoir, it appears that the rate of predation is low. Similarly, no trout were found in the stomachs of burbot (42 specimens examined). This means that the success of the planting program for the reservoir was probably not diminished by the presence of predacious species. 
Table 17. Mean fork length $(\mathrm{mm})$ of white sucker at age $3+$ and $6+$ years in various lakes.

\begin{tabular}{lccc}
\hline & \multicolumn{2}{c}{ Age (Years) } & \\
\cline { 2 - 3 } Lake & $3+$ & $6+$ & Reference \\
\hline Gleniffer, AB (1984) & 312 & 408 & This study \\
Gleniffer, AB (1985) & 338 & 586 & This study \\
Gleniffer, AB (1986) & 305 & 520 & This study \\
Gleniffer, AB (1987) & 295 & 454 & This study \\
Wasksiv, SK & 120 & 300 & 1 \\
Muskellunge, WI & 163 & 262 & 1 \\
Lake of the Woods, ON & 284 & 396 & 1 \\
George, ON & 336 & 452 & 2 \\
Michigan, WI & 362 & 430 & 2 \\
Winnebago, WI & 406 & $498^{\circ}$ & \\
\hline
\end{tabular}

SOURCES: 1. Scott and Crossman (1973)

2. Becker (1983)

a females only

Table 18. Mean fork length (mm) of longnose sucker at age $3+$ and $6+$ years in various lakes and rivers.

Gleniffer, $A B$ (1984)

Gleniffer, $A B$ (1985)

Gleniffer, $A B$ (1986)

Gleniffer, $A B$ (1987)

Pyramid, $A B$

Great Slave Lake (northern), NWT

Great Slave Lake (whole lake), NWT

Great Slave Lake (southern), NWT

North Saskatchewan River, SK
306

340

385

265

107

170

177

203

323
384

433

417

415

178

314

288

308

439
This study

This study

This study

This study

SOURCES: 1. Scott and Crossman (1973)

2. Harris (1962) 
The diet of the other species examined in this study is typical of that reported elsewhere in Canada and the USA (Scott and Crossman, 1973; Becker, 1983).

\section{REFERENCES}

Alberta Environmental Centre. 1989a. Species composition and angler use of fish in Gleniffer Lake (Dickson Dam reservoir). Alberta Environmental Centre, Vegreville, AB. AECV89-R5. 38 pp.

Alberta Environmental Centre. 1989b. A five-year study of mercury in fish from a newly formed reservoir (Gleniffer Lake, Alberta). Alberta Environmental Centre, Vegreville, AB. AECV89-R4. 24 pp. Alberta Forestry, Lands and Wildlife. 1983-1986. Unpublished data.

Fish and Wildlife Division, St. Paul, AB.

Alberta Forestry, Lands and Wildife. 1989. Unpublished data. Fish and Wildlife Division, Edmonton, $A B$.

Becker, G. 1983. Fishes of Wisconsin. University of Wisconsin

Press. Madison, WI. 1052 pp.

Bodaly, R.A., T.W.D. Johnson, R.J.P. Fudge, and J.W. Clayton. 1984.

Collapse of the lake whitefish (Coregonus clupeaformis) fishery in Southern Indian Lake, Manitoba, following lake impoundment and river diversion. Can. J. Fish. Aquat. Sci. 41:692-700.

Fish Planting Lists. 1983-1987. Fish and Wildlife Division, Alberta Forestry, Lands and Wildlife, Edmonton, $A B$. 
Fudge, R.J.P., and R.A. Bodaly. 1984. Postimpoundment winter sedimentation and survival of lake whitefish (Coregonus clupeaformis) eggs in Southern Indian Lake, Manitoba. Can. J. Fish. Aquat. Sci. 41:701-705.

Harris, Roy H.D. 1962. Growth and reproduction of the longnose sucker, Catostomus catostomus, in Great Slave Lake. J. Fish. Res. Bd. Can. 19:113-126.

Larkin, P.A., J.G. Terpenning, and R.R. Parker. 1956. Size as a determinant of growth rate in rainbow trout. Trans. Am. Fish. Soc. $86: 84-96$.

McHugh, J.L. 1941. Growth of the Rocky Mountain whitefish. J. Fish. Res. Bd. Can. 5:337-343.

Rawson, D.S., and C.A. Elsey. 1948. Reduction in the longnose sucker population of Pyramid Lake, Alberta, in an attempt to improve angling. Trans. Amer. Fish. Soc. 78:13-31.

Scott, W.B., and E.J. Crossman. 1973. Freshwater fishes of Canada. Fish. Res. Bd. Can. Bul1. 184:641-645. 


